\title{
1 Transcriptional landscape of PTEN loss in primary prostate
}

\section{2 cancer}

3

$\operatorname{Lotan}^{2,3}$, and Luigi Marchionni ${ }^{1,5, *}$

7

*Correspondence to: lum4003@med.cornell.edu
${ }^{1}$ Department of Pathology and Laboratory Medicine, Weill Cornell Medicine, New York, NY, USA

${ }^{2}$ Department of Oncology, Johns Hopkins University School of Medicine, Baltimore, MD, USA

${ }^{3}$ Departamento de Bioquímica e Imunologia, ICB, Universidade Federal de Minas Gerais, Belo Horizonte, MG, Brazil

${ }^{4}$ Department of Pathology, Johns Hopkins University School of Medicine, Baltimore, MD, USA

${ }^{5}$ Department of Biostatistics, Harvard T.H. Chan School of Public Health, Boston, MA, USA

${ }^{6}$ Department of Urology, Northwestern University, Evanston, IL, US 
bioRxiv preprint doi: https://doi.org/10.1101/2020.10.08.332049; this version posted October 9,2020 . The copyright holder for this preprint (which was not certified by peer review) is the author/funder, who has granted bioRxiv a license to display the preprint in perpetuity. It is made available under aCC-BY-NC 4.0 International license.

\section{ABSTRACT}

PTEN is the most frequently lost tumor suppressor in primary prostate cancer (PCa) and its loss is associated with aggressive disease. However, the transcriptional changes associated with PTEN loss in PCa have not been described in detail. Here, we applied a meta-analysis approach, leveraging two large PCa cohorts with experimentally validated PTEN and ERG status, to derive a transcriptomic signature of PTEN loss, while also accounting for potential confounders due to $E R G$ rearrangements. Strikingly, the signature indicates a strong activation of both innate and adaptive immune systems upon PTEN loss, as well as an expected activation of cell-cycle genes. Moreover, we made use of our recently developed FC-R2 expression atlas to expand this signature to include many non-coding RNAs recently annotated by the FANTOM consortium. With this resource, we analyzed the TCGA-PRAD cohort, creating a comprehensive transcriptomic landscape of PTEN loss in PCa that comprises both the coding and an extensive noncoding counterpart. 


\section{Introduction}

Previous molecular studies have explored the genomic heterogeneity of prostate adenocarcinomas (PCa) revealing distinct molecular subsets characterized by common genome alterations (1-3). Among these molecular alterations, loss of the tumor suppressor gene phosphatase and tensin homolog (PTEN) - which is implicated in the negativeregulation of the PI3K-AKT-mTOR pathway - has been identified as one of the most common genomic drivers of primary $\mathrm{PCa}(4,5)$. Since alterations in the PI3K pathway are present in more than $30 \%$ of human cancers, the identification of an expression signature associated with PTEN loss has been investigated in different tumor contexts, including breast, bladder, lung, and PCa $(6,7)$.

Assessment of PTEN status by fluorescence in situ hybridization (FISH) and immunohistochemistry (IHC) in large clinical PCa cohorts has shown a consistent association with adverse pathological features such as high Gleason score, extra-prostatic extension, as well as prognostic value for biochemical recurrence and cancer-related death $(4,8)$. IHCbased assessment of PTEN status has been shown to correlate tightly with genomic alterations of the PTEN locus and captures not only loss of the gene, but also mutation and epigenetic changes that lead to PTEN functional inactivation $(4,9,10)$ and the potential clinical utility of PTEN IHC as a valuable prognostic marker has been demonstrated previously (11-14).

Though PTEN is involved in a myriad of cellular processes spanning cellular proliferation to tumor microenvironment interactions (5), the transcriptional landscape related to PTEN expression has not yet been explored in depth, and the role of long non-coding RNAs (IncRNAs) remains elusive (15). These observations, added to the evidence that subtle PTEN downregulation can lead to cancer susceptibility (16), demonstrate the important role of PTEN in cancer biology but also highlight the need for additional studies.

Similarly, gene rearrangements of the ETS transcription factor, ERG, with the androgen-regulated gene Transmembrane Serine Protease 2 (TMPRSS2) are present in $\sim 50 \%$ of PCa from patients of European descent. TMPRSS2-ERG fusion (herein denoted as $E R G^{+}$for fusion present and $E R G^{-}$for absence of fusion) has been shown to activate the PI3K-kinase pathway similarly to PTEN loss (17), leading to increased proliferation and invasion. Importantly, tumors harboring TMPRSS2-ERG rearrangements show an enrichment for PTEN loss $(17,18)$. The co- 
occurrence of these two genomic alterations makes it challenging to dissect the contributions of each to the

transcriptomic landscape.

The goal of this study was to elucidate the transcriptional landscape of PTEN loss in PCa through the analysis of two large and very well clinically-curated cohorts, for which PTEN and ERG status was assessed by clinical-grade IHC: The Natural History (NH) cohort, in which patients that underwent radical prostatectomy for clinically localized PCa did not receive neoadjuvant therapy or adjuvant hormonal therapy prior to documented distant metastases (19); and the Health Professionals Follow-up Study (HPFS) cohort in which the patients were followed for over 25 years (20). Based on IHC-assessed PTEN status for these cohorts, we built a PTEN-loss signature highly concordant across the independent datasets, in both presence and absence of TMPRSS2-ERG fusion. Overall, this PTEN-loss signature was associated with cellular processes associated with aggressive tumor behavior (e.g., increased motility and proliferation) and, surprisingly, with increases in gene sets related to the immune response. In addition, through our recently developed FANTOM-CAT/recount2 (FC-R2) resource (21) and copy-number-variation data, we expanded this signature beyond coding genes and report the non-coding RNA repertory resulting from PTEN loss. 


\section{Methods}

\section{Data collection and Immunostaining}

All expression data used in this work were gathered from public domain databases. In this work, we made use of three cohorts: FC-R2 TCGA, Natural History (NH), and Health Professionals Follow-up Study (HPFS). Information about each cohort is summarized in Table 1. Information about PTEN status by immunohistochemistry for the HPFS cohort was readily available and therefore obtained from the public domain. For NH cohort samples, IHC staining for PTEN and ERG were performed using a previously validated protocol (22). Last, for TCGA we used the Copy Number Variation (CNV) called by the GISTIC algorithm to define PTEN status and expectation-maximization algorithm to define ERG status.

\section{Meta-analysis of NH and HPFS cohorts}

We performed a meta-analysis approach using a Bayesian hierarchical multi-level model (BHM) for cross-study detection of differential gene expression implemented in the Bioconductor package XDE (23) on microarray-based cohorts to obtain a PTEN-null signature from PTEN IHC validated samples. The model was fitted using the delta gp model with empirical starting values and 1000 bootstraps were performed. All remaining parameters were set to default values. This analysis was also performed stratifying the samples by ERG status to evaluate the impact of the $E R G$ rearrangement in the signature.

\section{Differential expression analysis in the TCGA cohort}

A generalized linear model (GLM) approach coupled with empirical Bayes moderation of standard errors and voom precision weigths $(24,25)$ was used to detect differentially expressed genes in the TCGA cohort. The models were adjusted for surrogate variables with the SVA package (26). Adjusted p-values controlling for multiple hypothesis testing were performed using the Benjamini-Hochberg method and genes with false discovery rate (FDR) equal or less than 0.1 were reported (27).

\section{Gene set enrichment analysis (GSEA)}

The results from the meta-analysis performed in the NH and HPFS cohort were ranked by the weighted size effect (average of the posterior probability of concordant differential expression multiplied by the Bayesian effect size of 

available under aCC-BY-NC 4.0 International license.

each cohort). The results from the TCGA cohort were ranked by t-statistics. Ranked lists were tested for gene set enrichment. Gene set enrichment analysis (GSEA) was performed using a Monte Carlo adaptive multilevel splitting approach, implemented in the fgsea (28) package. A collection of gene sets (Hallmarks, REACTOME, and GO Biological Processes) were obtained from the Broad Institute MSigDB database. The androgen response gene set was obtained from Scheaffer et al (29). Gene sets with less than 15 and more than 1500 genes were removed from the analysis, except for the GO biological processes whose max size was set to 300 to avoid overly generic gene sets. The enriched pathways were collapsed to maintain only independent ones using the function collapsePathways from fgsea. 


\section{Results}

\section{Meta-analysis of Natural History and Health Professionals Follow-Up Study cohorts}

We sought to obtain a consensus signature of PTEN loss that could be reproduced across independent cohorts. We utilized a meta-analysis approach leveraging a multi-level model for cross-study detection of differential gene expression (DGE). We fitted a Bayesian hierarchical model (BHM) for analysis of differential expression across multiple studies that allowed us to aggregate data from two previously described tissue microarray-based cohorts where PTEN and ERG status was determined by IHC (Table 1 and Figure 1) and we derived a PTEN-loss signature (Figure 2). In this analysis, we observed 813 genes for which the differential expression was highly concordant (Bayesian Effect Size (BES) $\geq 1$, posterior probability of concordant differential expression (PPCDE) $\geq 0.95)$ (Table S1).

The consequences of PTEN loss on cell cycle regulation and tumor cell invasion has been extensively reported previously $(4,30,31)$. Accordingly, beyond PTEN itself, the top DEG genes in our signature reflected this profile (Figure 2 and Table S1). Dermatopontin $(D P T)(B E S=-2.59, \mathrm{PPCDE}=1)$ and Alanyl membrane aminopeptidase $($ ANPEP) $(\mathrm{BES}=$ -2.53, PPCDE $=1)$ were found down-regulated upon PTEN loss. Leucine-Rich Repeat Neuronal $1(L R R N 1)$ was among the genes up-regulated upon PTEN loss (BES = 3.36, PPCDE $=1$ ). These and other genes found differentially expressed upon PTEN loss have all been shown to be associated with a more aggressive phenotype in several cancer types (5) .

Notably, we found $E R G$ among the top upregulated genes in the signature (Figure 2). As expected $(18,32,33)$, ERG rearrangement was more common among cases with PTEN loss compared to intact PTEN in all cohorts (Fisher exact test, $\mathrm{p} \leq 0.001)$. Given this enrichment, it was not surprising that $E R G$ was among the most up-regulated genes in the BHM signature, as well as PLA2G7, which has been shown to be among the most highly overexpressed genes in ERG-rearranged PCa compared to those lacking ERG rearrangements (34). The presence of ERG and ERG-regulated transcripts in the PTEN-loss signature suggested that this signature might be confounded by enrichment of ERG rearranged tumors among the tumors with PTEN loss.

Since ERG rearrangements represent a major driver event in PCa and PTEN loss is enriched in ERG-rearranged tumors, we next investigated the role of ERG in our PTEN-loss signature. To this end, we repeated the Bayesian hierarchical model for the analysis of differential expression by stratifying the samples by ERG status. In the background with $E R G$ rearrangement, we observed a similar signature to the previous overall PTEN-loss signature, but without the aforementioned $E R G$-associated genes (Supplementary figure S1 and Supplementary table S2). However, in the 
bioRxiv preprint doi: https://doi.org/10.1101/2020.10.08.332049; this version posted October 9,2020 . The copyright holder for this preprint (which was not certified by peer review) is the author/funder, who has granted bioRxiv a license to display the preprint in perpetuity. It is made available under aCC-BY-NC 4.0 International license.

absence of ERG rearrangement, we could not find any significant differences between samples with or without PTEN

loss. This was unexpected given that PTEN is a powerful tumor suppressor capable of triggering multiple molecular changes.

\section{Extending the PTEN-loss signature}

To validate our PTEN loss signatures in an orthogonal cohort, we next examined the TCGA PRAD cohort (35), where PTEN status was estimated by genomic copy number $(\mathrm{CN})$ assessment, which was closely aligned with PTEN gene expression (Figure S3). We recently developed a comprehensive expression atlas based on the FANTOM-CAT annotations. This meta-assembly is currently the broadest collection of the human transcriptome $(21,36)$. These gene models include many novel IncRNA categories such as enhancers and promoters, allowing the signature to be further expanded beyond the coding repertoire. We used TCGA expression data from the FC-R2 expression atlas (21) to perform DGE analysis stratified by the PTEN status as derived from $\mathrm{CN}$ analysis. We also performed the same analysis in a stratified manner as in the HPFS and NH cohorts, using the ERG expression with expectation maximization (EM) algorithm to define ERG status given the bimodal nature of ERG expression in PCa. Interestingly, we were able to detect differential expression between PTEN-null and PTEN-intact samples without ERG rearrangement in the TCGA cohort, which used high-throughput sequencing as opposed to gene expression microarrays, suggesting that there the lack of signal in the previous analysis can be a reflection of the potential limitations with the later technology.

We observed 521 differentially expressed genes (DEG) when comparing PTEN-null and PTEN-wild-type samples (FDR $\leq 0.01$, LogFC $\geq 1$ ), of which 257 were coding genes and 264 were non-coding genes (Supplementary Table S3). When stratifying the samples by ERG status, we obtained 435 and 364 DEG in the background with and without ERG rearrangement (Supplementary Table S4 and S5), respectively, with similar proportions of coding and non-coding genes. Using Correspondence-at-the-top (CAT) analysis of the coding genes, we observed a higher concordance than expected by chance between the TCGA PTEN-loss signature and that from the BHM (Figure S4). This confirmed that $\mathrm{CN}$ is a reasonable proxy to IHC-staining in TCGA which allowed us to expand this signature beyond coding RNAs.

In this analysis, we were able to detect a variety of IncRNAs that are already known to be involved in PCa development and progression. Notably, several differentially expressed IncRNAs were already reported to be 
associated with PCa (37-46) (e.g. PCA3, PCGEM1, SCHLAP1, KRTAP5-AS1, Mir-596) (Supplementary Table S3-S5). PCA3

is a prostate-specific IncRNA overexpressed in PCa tissue. Similarly, IncRNA PCGEM1 expression is increased and highly specific in PCa where it promotes cell growth and it has been associated with high-risk PCa patients $(41,42)$. On the other hand, KRTAP5-AS1 expression has not been directly associated with PCa.

Also ranked high among IncRNAs differentially expressed were the IncRNAs SChLAP1 and its uncharacterized antisense neighbor AC009478.1. SchLAP1 is overexpressed in a subset of PCa where it antagonizes the tumorsuppressive function of the SWI/SNF complex and can independently predict poor outcomes $(45,46)$. On the other hand, the role of AC009478.1 in PCa development is still unknown. Interestingly, SchLAP1 and AC009478.1 expression is strongly correlated in the TCGA datasets only in PCa $(R=0.94, p<2.2 e-26)$ and bladder cancer $(R=0.85, p<2.2 e-$ 26) (Figure S5).

Strikingly, a substantial proportion of IncRNAs associated with PTEN loss were not yet associated with PCa. Out of the 264 DE non-coding genes, 134 were novel and annotated only in the FANTOM-CAT meta-assembly annotation (Table 2). Among the FANTOM-CAT exclusive genes, those with the highest fold change in close proximity with coding genes were CATG00000038715, CATG00000079217, and CATG00000117664 (Figure S6). These genes were mostly expressed in PCa as opposed to other cancer types in the TCGA dataset (Figure 3).

Among the downregulated genes were CATG00000038715 and CATG00000079217. CATG00000038715 is in close proximity to CYP4F2 and CYP4F11, encoding members of the cytochrome P450 enzyme superfamily. Expression of CATG00000038715 and CYP4F2 are highly correlated ( $\mathrm{R}=0.91, \mathrm{p}<2.2 \mathrm{e}-16)$ in $\mathrm{PCa}$, and expression of the former was highly specific for PCa (Figure S7). CATG00000079217 is in close proximity to the coding gene FBXL7, an F-box gene which is a component of the E3 ubiquitin ligase complex. While expression of FBXL7 and CATG00000079217 showed only a weak correlation $(\mathrm{R}=0.14, \mathrm{p}<7.4 \mathrm{e}-4)$, CATG00000079217 expression was notably higher in PCa and breast cancer than in other cancers, and it was moderately correlated with several PCa biomarkers (e.g. KLK2, KLK3, STEAP2, PCGEM1, SLC45A3) $(41,42,47-51)(\mathrm{R}=0.37-0.57, \mathrm{p}<2.2 \mathrm{e}-16)$ in TCGA.

CATG00000117664 was among the most upregulated IncRNA and it is located near GPR158, a G protein coupled receptor highly expressed in brain. The expression between GPR158 were correlated $(\mathrm{R}=0.54, \mathrm{p}<2.2 \mathrm{e}-16)$, and CATG00000117664 expression was shown to be highly specific to PCa (52) (Figure S7). 


\section{PTEN loss induces the innate and adaptive immune system}

184 We performed Gene Set Enrichment Analysis (GSEA) using fgsea (28) and tested both the BHM- and TCGA-generated

molecular signatures for enrichment in three collections of the Molecular Signature Database $(\mathrm{MSigDB})(53,54)$ :

HALLMARKS, REACTOME, and GO Biological Processes (BP). Results were similar in both signatures, with positive

enrichment of proliferation and cell cycle-related gene sets (e.g. MYC1 targets, MTORC1 signaling, cell cycle

checkpoints, and DNA repair) and both innate and adaptive immune system associated gene sets (e.g. Neutrophil

degranulation, MHC antigen presentation, interferon-alpha, and gamma) (Figure 4-5 and Supplementary Table S6-

S20). The positive enrichment of MHC antigen presentation, interferon-alpha and -gamma in PTEN-null tumors is

Since PTEN-null tumors are known to have decreased androgen output, which is a strong suppressor of

inflammatory immune cells $(29,56,57)$, we hypothesized that this decrease in androgen levels could activate an

immune response. We, therefore, performed a GSEA analysis using a collection of androgen-regulated genes from 


\section{Discussion}

With an estimated prevalence of up to $50 \%$, PTEN loss is recognized as one of the major driving events in PCa (58). PTEN antagonizes PI3K-AKT/PKB and is a key modulator of the AKT-mTOR signaling pathways which are important in regulating cell growth and proliferation. Accordingly, PTEN loss is consistently associated with more aggressive disease features and poor outcomes. Saal and collaborators previously generated a transcriptomic signature of PTEN loss in breast cancer (6). While this signature was correlated with worse patient outcomes in breast and other independent cancer datasets, including PCa, the signature unsurprisingly fails to capture key characteristics of PCa such as ERGrearrangement $(6,11)$. Significantly, a transcriptomic signature reflecting the landscape of PTEN loss in PCa has not been described to date.

Immunohistochemistry (IHC) assay is a clinically utilized technique to determine the status of the PTEN gene, with high sensitivity and specificity for underlying genomic deletions (59) (Figure 1). Therefore, we analyzed transcriptome data from two large PCa cohorts - the Health Professional Follow-up Study (HPFS) and the Natural History (NH) study - for which IHC-based PTEN and ERG status was available ( $n=390$ and 207, respectively), deriving a PTEN-loss gene expression signature specific to PCa (Figure 2 and Supplementary Table S1). Genes that are associated with increased proliferation and invasion in several cancer types, such as DPT, ANPEP and LRRN1, were among the most concordant DEG in this signature. DPT has been shown to inhibit cell proliferation through MYC repression and to be down-regulated in both oral and thyroid cancer $(60,61)$. It has also been shown to control cell adhesion and invasiveness, with low expression leading to a worst prognosis $(61,62)$. ANPEP is known to play an important role in cell motility, invasion, and metastasis progression $(62,63)$, and lower expression of this gene has been associated with the worst prognosis (64). LRRN1 is a direct transcriptional target of MYCN, and an enhancer of EGFR and IGRF signaling pathway (65). Higher levels of LRRN1 expression promote tumor cell proliferation, inhibiting cell apoptosis, and play an important role in preserving pluripotency-related proteins through $A K T$ phosphorylation (65-67), leading to a poor clinical outcome in gastric and brain cancer.

Notably, ERG was shown to be upregulated in our signature, which led us to perform a stratified analysis to avoid capturing signals driven mostly by ERG overexpression. Surprisingly, we were not able to detect significant differences by PTEN status in the HPFS and NH cohorts, which were quantified by gene expression microarrays, in the ERG samples. Conversely, when analyzing the TCGA cohort, we were able to detect significant changes by PTEN status 
in the ERG samples (Supplementary Tables S3-S5). However, given the known limitations of gene expression

microarrays performed on formalin fixed material, such as the limited dynamic range of expression values (68), we believe that the HPFS and NH datasets were limited by the technology employed. Nevertheless, concordance between the BHM- and TCGA- cohorts were similar in both the overall and the $E R G^{+}$background comparison (Supplementary Figure S4).

We observed in the TCGA cohort several IncRNAs that have already been associated with PCa progression were found in our signature. PCA3 acts by a variety of mechanisms such as down-regulation of the oncogene PRUNE2 and up-regulation of the PRKD3 gene by acting as a miRNA sponge for mir-1261 leading to increase proliferation and migration(37,38). Conversely, knockdown of PCA3 can lead to partial reversion of epithelial-mesenchymal transition (EMT) (39) which can lead to increased cell invasion, motility, and survival (40). Although KRTAP5-AS1 has not been associated with PCa, it has recently shown that KRTAP5-AS1 can act as a miRNA sponge for miRNAs, such as mir-596, which targets the oncogene CLDN4 which enhances the invasion capacity of cancer cells and promote EMT $(40,43)$, thereby overexpression of KRTAP5-AS1 can lead increased levels of CLDN4 (44). Mir-596 has also been shown to be overexpressed in response to androgen signaling and associated with anti-androgen therapy resistance (44).

Moreover, many IncRNAs exclusively annotated in the FANTOM-CAT were associated with PTEN-loss and were shown to be expressed mostly in PCa (Figure 3). Since these genes are novel genes without elucidated function, we analyzed potential roles for these genes by looking at coding genes located in the same loci. Among the top DE IncRNAs, genes within proximity to coding genes were CATG00000038715, CATG00000079217, and CATG00000117664 (Figure S6) which are positioned in the same loci as CYP4F2, FBXL7, and GPR158, respectively. CYP4F2 is involved in the process of inactivating and degrading leukotriene B4 (LTB4). LTB4 is a key gene in the inflammatory response that is produced in leukocytes in response to inflammatory mediators and can induce the adhesion and activation of leukocytes on the endothelium.(69). FBXL7 regulates mitotic arrest by degradation of $A U R K A$, which is known to promote inflammatory response and activation of NF-KB $(70,71)$. Likewise, increase expression of GPR158 is reported to stimulate cell proliferation in PCa cell lines, and it is linked to neuroendocrine differentiation (72).

We consistently observed a strong enrichment in immune response genes and gene sets upon PTEN loss (Figure 4 and Supplementary Tables S6-S20). Immune-associated genes (i.e. GP2 and PLA2G2A) were found amongst 
the top up-regulated genes in our signature (Figure 2). Positive enrichment of Interferon-alpha- and gamma-response genes (FDR $\leq 0.01)$ further suggests that a strong immuno-responsive environment, with both innate and adaptive systems activated, is developed in PTEN-null tumors (Figure 5). The positive enrichment of MHC class II antigen presentation, neutrophil degranulation, vesicle-mediated transport, and FC receptor pathway-related genes suggests that PTEN-null tumors may be immunogenic (Figure 4). This finding was particularly surprising given that PTEN is itself a key positive regulator of innate immune response, controlling the import of IRF3, which is responsible for IFN production. Accordingly, disruption of PTEN expression has previously been reported to lead to decreased innate immune response (73). Conversely, it has also been hypothesized that the increased genomic instability caused by, or associated with, PTEN loss can increase immunogenicity in the tumor micro-enviroment (TME) (74). This finding is of particular interest given that immune-responsive tumors can be good candidates for immunotherapy-based approaches.

Remarkably, despite loss of PTEN being associated with higher expression of the immune checkpoint gene programmed death ligand-1 $(P D-L 1)$ in several cancer types $(75,76)$ this is not true in PCa $(77)$. So far, current immunotherapeutic interventions, such as PD-1 blockade, in PCa have not been successful. One of the possible reasons is the lack of $P D-L 1$ expression (77). Therefore, alternative targets must be considered for immunotherapy in PCa. One alternative target is the checkpoint molecule $B 7-H 3(C D 276)$, whose expression has already been associated with PCa progression and worse prognosis (78) and has been suggested as a target for immunotherapy $(79,80)$. CD276 was one of the most concordant up-regulated genes in our signature (Figure 2) suggesting that its expression is associated with PTEN loss. Interestingly, B7-H3 expression may be down-regulated by androgens (81).

The effects of androgen on the immune system has already been extensively studied and reviewed (56). Androgens are known to suppress inflammatory immune cells and to impair the development and function of B-and T-cells (57). We, therefore, hypothesized that the decreased levels of androgen in PTEN-null TME could lead to an unsuppressed immune system. By testing our signature for enrichment in androgen-related genes (AR) derived from Schaeffer et al. (29), we observed that upon PTEN-loss, androgen-sensitive genes that are typically suppressed by DHT are positively enriched, indicating that androgen levels or androgen response in PTEN-null tumors may be lower than in their PTEN-intact counterparts (Figure S8). This decrease in AR-signaling has been described in PTEN-null tumors, in 

available under aCC-BY-NC 4.0 International license.

278 which activation of PI3K pathway inhibits AR activity. (82). Furthermore, AR inhibition activates AKT signaling by 279 inhibiting AKT phosphatase levels further boosting cell proliferation (82), which has also been noted in this study 280 (Figure 3). Finally, in the non-coding repertoire, both PCA3 and PCGEM1 are modulated by androgen $(83,84)$ and were 281 down-regulated upon PTEN loss which tracks with the observed decreased androgen response in PTEN-null tumors 282 (Figure S6 and S8). 


\section{Conclusion}

Altogether, we have generated a highly concordant gene signature for PTEN loss in PCa across three independent

datasets. We show that this signature was highly enriched in proliferation and cell cycle genes, leading to a more

aggressive phenotype upon PTEN loss, which is concordant with the literature. Moreover, we have shown that PTEN

loss is associated with an increase in both innate and adaptive immune response. Although the literature shows that

PTEN loss usually leads to immuno-suppression, we find evidence that this finding may be reversed in PCa. This

observation has potential implications in the context of precision medicine since immune responsive tumors are more

likely to respond to immunotherapies. Therefore, PTEN-null tumors might benefit more from this approach than PTEN-

intact tumors. Potentially, PTEN status can guide immunotherapy combination with other approaches such as androgen ablation.

Finally, by leveraging the FC-R2 resource, we were able to highlight many IncRNAs that may be associated with

PCa progression. Although functional characterization these IncRNAs is beyond the scope of this study, we have shown

that these novel IncRNAs are highly specific to PCa and track with several coding mRNAs and IncRNAs already reported

to be involved in PCa development and progression, most notably, genes involved in immune response. By providing a

PCa-specific signature for PTEN loss, as well as highlighting potential new players, we hope to empower further studies 


\section{Acknowledgments}

This publication was made possible through support from the National Institutes of Health-National Cancer Institute

(NIH-NCl) grants U01CA196390, and R01CA200859; and the U.S. Department of Defense (DoD) office of the Congressionally Directed Medical Research Programs (CDMRP) award W81XWH-16-1-0739 and W81XWH-16-1-0737; and Fundação de Amparo a Pesquisa do Estado de Minas Gerais award BDS-00493-16.

\section{Author contributions statement}

L.M. and T.L. conceived the idea; L.M., E.L.I. and T.L. designed the study; E.L.I., D.F.S., W.D., T.L., and L.M. performed the analysis; E.L.I., D.F.S., T.L., T.V., G.R.F., and L.M. interpreted the results; T.L., E.M.E., S.T., L.M., M.L., and E.M.S. provided data and tools; E.L.I., D.F.S., T.L., and L.M. wrote the manuscript; all authors reviewed and approved the manuscript. 
bioRxiv preprint doi: https://doi.org/10.1101/2020.10.08.332049; this version posted October 9.2020. The copyright holder for this preprint (which was not certified by peer review) is the author/funder, who has granted bioRxiv a license to display the preprint in perpetuity. It is made available under aCC-BY-NC 4.0 International license.

\section{References}

1. Cancer Genome Atlas Research Network, TCGA. The Molecular Taxonomy of Primary Prostate Cancer. Cell [Internet]. 2015 Nov 5;163(4):1011-25. Available from: http://www.ncbi.nlm.nih.gov/pubmed/26544944

2. Taylor BS, Schultz N, Hieronymus H, Gopalan A, Xiao Y, Carver BS, et al. Integrative genomic profiling of human prostate cancer. Cancer Cell. 2010;18(1):11-22.

3. Baca S, Garraway L. The genomic landscape of prostate cancer. Front Endocrinol (Lausanne) [Internet]. 2012;3:69. Available from: https://www.frontiersin.org/article/10.3389/fendo.2012.00069

4. Jamaspishvili T, Berman DM, Ross AE, Scher HI, De Marzo AM, Squire JA, et al. Clinical implications of PTEN loss in prostate cancer. Nat Rev Urol [Internet]. 2018;15(4):222-34. Available from: http://dx.doi.org/10.1038/nrurol.2018.9

5. Lee Y-R, Chen M, Pandolfi PP. The functions and regulation of the PTEN tumour suppressor: new modes and prospects. Nat Rev Mol Cell Biol [Internet]. 2018;19(9):1-16. Available from: http://dx.doi.org/10.1038/s41580-018-0015-0

6. Saal LH, Johansson P, Holm K, Gruvberger-Saal SK, She Q-BBQ-B, Maurer M, et al. Poor prognosis in carcinoma is associated with a gene expression signature of aberrant PTEN tumor suppressor pathway activity. Proc Natl Acad Sci [Internet]. 2007 May 1;104(18):7564-9. Available from: http://www.pnas.org/content/104/18/7564

7. Ong CW, Maxwell P, Alvi MA, McQuaid S, Waugh D, Mills I, et al. A gene signature associated with PTEN activation defines good prognosis intermediate risk prostate cancer cases. J Pathol Clin Res. 2018;4(2):103-13.

8. Morais CL, Han JS, Gordetsky J, Nagar MS, Anderson AE, Lee S, et al. Utility of PTEN and ERG immunostaining for distinguishing high-grade PIN from intraductal carcinoma of the prostate on needle biopsy. Am J Surg Pathol [Internet]. 2015 Feb;39(2):169-78. Available from: http://www.ncbi.nlm.nih.gov/pubmed/25517949

9. Lotan TL, Wei W, Ludkovski O, Morais CL, Guedes LB, Jamaspishvili T, et al. Analytic validation of a clinical-grade PTEN immunohistochemistry assay in prostate cancer by comparison with PTEN FISH. Nat Genet. 2016;29(8):904-14.

10. Lotan TL, Heumann A, Rico SD, Hicks J, Lecksell K, Koop C, et al. PTEN loss detection in prostate cancer: comparison of PTEN immunohistochemistry and PTEN FISH in a large retrospective prostatectomy cohort. Oncotarget. 2017;8(39):65566-76.

11. Han B, Mehra R, Lonigro RJ, Wang L, Suleman K, Menon A, et al. Fluorescence in situ hybridization study shows association of PTEN deletion with ERG rearrangement during prostate cancer progression. Mod Pathol [Internet]. 2009 Aug 1;22(8):1083-93. Available from: http://www.nature.com/articles/modpathol200969

12. Leapman MS, Nguyen HG, Cowan JE, Xue L, Stohr B, Simko J, et al. Comparing Prognostic Utility of a Single-marker Immunohistochemistry Approach with Commercial Gene Expression Profiling Following Radical Prostatectomy. Eur Urol [Internet]. 2018;74(5):668-75. Available from: http://www.ncbi.nlm.nih.gov/pubmed/30181067 
13. Ahearn TU, Pettersson A, Ebot EM, Gerke T, Graff RE, Morais CL, et al. A Prospective Investigation of PTEN Loss and ERG Expression in Lethal Prostate Cancer. J Natl Cancer Inst [Internet]. 2016 Feb;108(2). Available from: http://www.ncbi.nlm.nih.gov/pubmed/26615022

14. Lotan TL, Tomlins SA, Bismar TA, Van der Kwast TH, Grignon D, Egevad L, et al. Report From the International Society of Urological Pathology (ISUP) Consultation Conference on Molecular Pathology of Urogenital Cancers. I. Molecular Biomarkers in Prostate Cancer. Am J Surg Pathol [Internet]. 2020 Jul;44(7):e15-29. Available from: http://www.ncbi.nlm.nih.gov/pubmed/32044806

15. Misawa A, Takayama KI, Inoue S. Long non-coding RNAs and prostate cancer. Cancer Sci. 2017;108(11):2107-14.

16. Alimonti A, Carracedo A, Clohessy JG, Trotman LC, Nardella C, Egia A, et al. Subtle variations in Pten dose determine cancer susceptibility. Nat Genet. 2010;42(5):454-8.

17. King JC, Xu J, Wongvipat J, Hieronymus H, Carver BS, Leung DH, et al. Cooperativity of TMPRSS2-ERG with PI3-kinase pathway activation in prostate oncogenesis. Nat Genet [Internet]. 2009 May;41(5):524-6. Available from: http://www.ncbi.nlm.nih.gov/pubmed/19396167

18. Carver BS, Tran J, Gopalan A, Chen Z, Shaikh S, Carracedo A, et al. Aberrant ERG expression cooperates with loss of PTEN to promote cancer progression in the prostate. Nat Genet [Internet]. 2009 May;41(5):619-24. Available from: http://www.nature.com/doifinder/10.1038/ng.370

19. Ross AE, Johnson MH, Yousefi K, Davicioni E, Netto GJ, Marchionni L, et al. Tissue-based Genomics Augments Postprostatectomy Risk Stratification in a Natural History Cohort of Intermediate- and High-Risk Men. Eur Urol [Internet]. 2016 Jan;69(1):157-65. Available from: http://www.ncbi.nlm.nih.gov/pubmed/26058959

20. Penney KL, Sinnott JA, Tyekucheva S, Gerke T, Shui IM, Kraft P, et al. Association of prostate cancer risk variants with gene expression in normal and tumor tissue. Cancer Epidemiol Biomarkers Prev [Internet]. 2015 Jan;24(1):255-60. Available from: http://www.ncbi.nlm.nih.gov/pubmed/25371445

21. Imada EL, Sanchez DF, Collado-Torres L, Wilks C, Matam T, Dinalankara W, et al. Recounting the FANTOM CAGE--Associated Transcriptome. Genome Res. 2020;30(7):gr--254656.

22. Lotan TL, Gurel B, Sutcliffe S, Esopi D, Liu W, Xu J, et al. PTEN Protein Loss by Immunostaining: Analytic Validation and Prognostic Indicator for a High Risk Surgical Cohort of Prostate Cancer Patients. Clin Cancer Res [Internet]. 2011 Oct 15;17(20):6563-73. Available from: http://clincancerres.aacrjournals.org/cgi/doi/10.1158/1078-0432.CCR-11-1244

23. Scharpf RB, Tjelmeland H, Parmigiani G, Nobel AB. A Bayesian model for cross-study differential gene expression. J Am Stat Assoc. 2009;104(488):1295-310. 
24. Smyth GK. Linear models and empirical bayes methods for assessing differential expression in microarray experiments. Stat Apl Genet Mol Biol [Internet]. 2004;3:Article3. Available from: http://www.ncbi.nlm.nih.gov/pubmed/16646809?dopt=abstract

25. Law CW, Chen Y, Shi W, Smyth GK. voom: precision weights unlock linear model analysis tools for RNA-seq read counts. Genome Biol [Internet]. 2014;15(2):R29. Available from: http://genomebiology.biomedcentral.com/articles/10.1186/gb2014-15-2-r29

26. Leek JT, Storey JD. Capturing heterogeneity in gene expression studies by surrogate variable analysis. PLoS Genet [Internet]. 2007 Sep;3(9):1724-35.

Available

from:

http://www.plosgenetics.org/article/info\%3Adoi\%2F10.1371\%2Fjournal.pgen.0030161

27. Benjamini $\mathrm{Y}$, Hochberg Y. Controlling the false discovery rate: a practical and powerful approach to multiple testing. J R Stat Soc $\quad$ [Internet $]$ $B,(1): 289-300$. Available from: http://www.dm.uba.ar/materias/analisis_expl_y_conf_de_datos_de_exp_de_marrays_Mae/2006/1/teoricas/FDR 1995.pdf

28. Sergushichev AA. An algorithm for fast preranked gene set enrichment analysis using cumulative statistic calculation. BioRxiv [Internet]. 2016;60012. Available from: https://www.biorxiv.org/content/10.1101/060012v1

29. Schaeffer EM, Marchionni L, Huang Z, Simons B, Blackman A, Yu W, et al. Androgen-induced programs for prostate epithelial growth and invasion arise in embryogenesis and are reactivated in cancer. Oncogene [Internet]. 2008 Dec 4;27(57):7180-91. Available from: http://www.ncbi.nlm.nih.gov/pubmed/18794802

30. Leinonen KA, Saramaki OR, Furusato B, Kimura T, Takahashi H, Egawa S, et al. Loss of PTEN Is Associated with Aggressive Behavior in ERG-Positive Prostate Cancer. Cancer Epidemiol Biomarkers Prev [Internet]. 2013 Dec 1;22(12):2333-44. Available from: http://cebp.aacrjournals.org/cgi/doi/10.1158/1055-9965.EPI-13-0333-T

31. Yoshimoto M, Ludkovski O, DeGrace D, Williams JL, Evans A, Sircar K, et al. PTEN genomic deletions that characterize aggressive prostate cancer originate close to segmental duplications. Genes, Chromosom Cancer. 2012;51(2):149-60.

32. Mehra R, Salami SS, Lonigro R, Bhalla R, Siddiqui J, Cao X, et al. Association of ERG/PTEN status with biochemical recurrence after radical prostatectomy for clinically localized prostate cancer. Med Oncol [Internet]. 2018 Oct 5;35(12):152. Available from: http://www.ncbi.nlm.nih.gov/pubmed/30291535

33. Krohn A, Freudenthaler F, Harasimowicz S, Kluth M, Fuchs S, Burkhardt L, et al. Heterogeneity and chronology of PTEN deletion and ERG fusion in prostate cancer. Mod Pathol. 2014;27(12):1612.

34. Massoner P, Kugler KG, Unterberger K, Kuner R, Mueller LAJ, Fälth M, et al. Characterization of transcriptional changes in 
ERG rearrangement-positive prostate cancer identifies the regulation of metabolic sensors such as neuropeptide Y. PLoS One [Internet]. 2013;8(2):e55207. Available from: http://www.ncbi.nlm.nih.gov/pubmed/23390522

35. Network CGAR, Weinstein JN, Collisson EA, Mills GB, Shaw KRM, Ozenberger BA, et al. The Cancer Genome Atlas PanCancer analysis project. Nat Genet [Internet]. 2013 Oct;45(10):1113-20. Available from: http://eutils.ncbi.nlm.nih.gov/entrez/eutils/elink.fcgi?dbfrom=pubmed\&id=24071849\&retmode=ref\&cmd=prlinks

36. Hon C-C, Ramilowski JA, Harshbarger J, Bertin N, Rackham OJLL, Gough J, et al. An atlas of human long non-coding RNAs with accurate $5^{\prime}$ ends. Nature [Internet]. 2017 Mar 1;543(7644):199-204. Available from: http://dx.doi.org/10.1038/nature21374

37. Salameh A, Lee AK, Cardó-Vila M, Nunes DN, Efstathiou E, Staquicini FI, et al. PRUNE2 is a human prostate cancer suppressor regulated by the intronic long noncoding RNA PCA3. Proc Natl Acad Sci [Internet]. 2015;112(27):8403-8. Available from: http://www.pnas.org/lookup/doi/10.1073/pnas.1507882112

38. He JH, Li BX, Han ZP, Zou MX, Wang L, Lv YB, et al. Snail-activated long non-coding RNA PCA3 up-regulates PRKD3 expression by miR-1261 sponging, thereby promotes invasion and migration of prostate cancer cells. Tumor Biol [Internet]. 2016;37(12):16163-76. Available from: http://dx.doi.org/10.1007/s13277-016-5450-y

39. Lemos AEGEGEG, Ferreira LB, Batoreu NM, de Freitas PP, Bonamino MH, Gimba ERP. PCA3 long noncoding RNA modulates the expression of key cancer-related genes in LNCaP prostate cancer cells. Tumor Biol [Internet]. 2016;37(8):11339-48. Available from: http://dx.doi.org/10.1007/s13277-016-5012-3

40. Agarwal R, D'Souza T, Morin PJ. Claudin-3 and claudin-4 expression in ovarian epithelial cells enhances invasion and is associated with increased matrix metalloproteinase-2 activity. Cancer Res. 2005;65(16):7378-85.

41. Srikantan V, Zou Z, Petrovics G, Xu L, Augustus M, Davis L, et al. PCGEM1, a prostate-specific gene, is overexpressed in prostate cancer. Proc Natl Acad Sci [Internet]. 2000;97(22):12216-21. Available from: http://www.pnas.org/cgi/doi/10.1073/pnas.97.22.12216

42. Petrovics G, Zhang W, Makarem M, Street JP, Connelly R, Sun L, et al. Elevated expression of PCGEM1, a prostate-specific gene with cell growth-promoting function, is associated with high-risk prostate cancer patients. Oncogene. $2004 ; 23(2): 605$.

43. Lin X, Shang X, Manorek G, Howell SB. Regulation of the epithelial-mesenchymal transition by claudin-3 and claudin-4. PLoS One. 2013;8(6):e67496.

44. Song YX, Sun JX, Zhao JH, Yang YC, Shi JX, Wu ZH, et al. Non-coding RNAs participate in the regulatory network of CLDN4 via ceRNA mediated miRNA evasion. Nat Commun [Internet]. 2017;8(1):1-16. Available from: http://dx.doi.org/10.1038/s41467-017-00304-1 
45. Prensner JR, Iyer MK, Sahu A, Asangani IA, Cao Q, Patel L, et al. The long noncoding RNA SChLAP1 promotes aggressive prostate cancer and antagonizes the SWI/SNF complex. Nat Genet. 2013;45(11):1392-403.

46. Mehra R, Udager AM, Ahearn TU, Cao X, Feng FY, Loda M, et al. Overexpression of the long non-coding RNA SChLAP1 independently predicts lethal prostate cancer. Eur Urol. 2016;70(4):549-52.

47. Kumar-Sinha C, Tomlins SA, Chinnaiyan AM. Recurrent gene fusions in prostate cancer. Nat Rev Cancer. 2008;8(7):497.

48. Nam RK, Zhang WW, Klotz LH, Trachtenberg J, Jewett MAS, Sweet J, et al. Variants of the hK2 protein gene (KLK2) are associated with serum hK2 levels and predict the presence of prostate cancer at biopsy. Clin cancer Res. 2006;12(21):64528.

49. Cicek MS, Liu X, Casey G, Witte JS. Role of androgen metabolism genes CYP1B1, PSA/KLK3, and CYP11\$ $\alpha \$$ in prostate cancer risk and aggressiveness. Cancer Epidemiol Prev Biomarkers. 2005;14(9):2173-7.

50. Whiteland H, Spencer-Harty S, Morgan C, Kynaston $\mathrm{H}$, Thomas DH, Bose P, et al. A role for STEAP2 in prostate cancer progression. Clin \\& Exp metastasis. 2014;31(8):909-20.

51. Perner S, Rupp NJ, Braun M, Rubin MA, Moch H, Dietel M, et al. Loss of SLC45A3 protein (prostein) expression in prostate cancer is associated with SLC45A3-ERG gene rearrangement and an unfavorable clinical course. Int J cancer. 2013;132(4):807-12.

52. Patel N, Itakura T, Jeong S, Liao C-P, Roy-Burman P, Zandi E, et al. Expression and Functional Role of Orphan Receptor GPR158 in Prostate Cancer Growth and Progression. Robson CN, editor. PLoS One [Internet]. 2015 Feb 18;10(2):e0117758. Available from: https://dx.plos.org/10.1371/journal.pone.0117758

53. Liberzon A, Subramanian A, Pinchback R, Thorvaldsdottir H, Tamayo P, Mesirov JP. Molecular signatures database (MSigDB) 3.0. Bioinformatics [Internet]. 2011 Jun 15;27(12):1739-40. Available from: https://academic.oup.com/bioinformatics/article-lookup/doi/10.1093/bioinformatics/btr260

54. Subramanian A, Tamayo P, Mootha VK, Mukherjee S, Ebert BL, Gillette MA, et al. Gene set enrichment analysis: a knowledge-based approach for interpreting genome-wide expression profiles. Proc Natl Acad Sci U S A [Internet]. 2005 Oct 25;102(43):15545-50. Available from: http://www.ncbi.nlm.nih.gov/pubmed/16199517

55. Kaur HB, Guedes LB, Lu J, Maldonado L, Reitz L, Barber JR, et al. Association of tumor-infiltrating T-cell density with molecular subtype, racial ancestry and clinical outcomes in prostate cancer. Mod Pathol [Internet]. 2018;31(10):1539-52. Available from: http://www.ncbi.nlm.nih.gov/pubmed/29849114

56. Trigunaite A, Dimo J, Jørgensen TN. Suppressive effects of androgens on the immune system. Cell Immunol [Internet]. 2015 Apr;294(2):87-94. Available from: http://www.ncbi.nlm.nih.gov/pubmed/25708485 
57. Ylitalo EB, Thysell E, Jernberg E, Lundholm M, Crnalic S, Egevad L, et al. Subgroups of Castration-resistant Prostate Cancer Bone Metastases Defined Through an Inverse Relationship Between Androgen Receptor Activity and Immune Response. Eur Urol [Internet]. 2017;71(5):776-87. Available from: http://www.ncbi.nlm.nih.gov/pubmed/27497761

58. Wise HM, Hermida MA, Leslie NR. Prostate cancer, PI3K, PTEN and prognosis. Clin Sci. 2017;131(3):197-210.

59. Lotan TL, Gurel B, Sutcliffe S, Esopi D, Liu W, Xu J, et al. PTEN protein loss by immunostaining: analytic validation and prognostic indicator for a high risk surgical cohort of prostate cancer patients. Clin Cancer Res [Internet]. 2011 Oct 15;17(20):6563-73. Available from: http://www.ncbi.nlm.nih.gov/pubmed/21878536

60. Guo Y, Li H, Guan H, Ke W, Liang W, Xiao H, et al. Dermatopontin inhibits papillary thyroid cancer cell proliferation through MYC repression. Mol Cell Endocrinol. 2019;480:122-32.

61. Yamatoji M, Kasamatsu A, Kouzu Y, Koike H, Sakamoto Y, Ogawara K, et al. Dermatopontin: a potential predictor for metastasis of human oral cancer. Int J cancer. 2012;130(12):2903-11.

62. Ishii K, Usui S, Sugimura Y, Yoshida S, Hioki T, Tatematsu M, et al. Aminopeptidase N regulated by zinc in human prostate participates in tumor cell invasion. Int J cancer. 2001;92(1):49-54.

63. Hashida H, Takabayashi A, Kanai M, Adachi M, Kondo K, Kohno N, et al. Aminopeptidase $\mathrm{N}$ is involved in cell motility and angiogenesis: its clinical significance in human colon cancer. Gastroenterology. 2002;122(2):376-86.

64. Sørensen KD, Abildgaard MO, Haldrup C, Ulhøi BP, Kristensen H, Strand S, et al. Prognostic significance of aberrantly silenced ANPEP expression in prostate cancer. Br J Cancer. 2013;108(2):420-8.

65. Hossain S, Takatori A, Nakamura Y, Suenaga Y, Kamijo T, Nakagawara A. LRRN1 enhances EGF-mediated MYCN induction in neuroblastoma and accelerates tumor growth in vivo. Cancer Res. 2012;72(17):4587-96.

66. Hossain MS, Ozaki T, Wang H, Nakagawa A, Takenobu H, Ohira M, et al. N-MYC promotes cell proliferation through a direct transactivation of neuronal leucine-rich repeat protein-1 (NLRR1) gene in neuroblastoma. Oncogene. 2008;27(46):607582.

67. Liao C-H, Wang Y-H, Chang W-W, Yang B-C, Wu T-J, Liu W-L, et al. Leucine-Rich Repeat Neuronal Protein 1 Regulates Differentiation of Embryonic Stem Cells by Post-Translational Modifications of Pluripotency Factors. Stem Cells. 2018;36(10):1514-24.

68. Wilhelm BT, Landry J-R. RNA-Seq-quantitative measurement of expression through massively parallel RNA-sequencing. Methods [Internet]. 2009 Jul;48(3):249-57. Available from: http://www.ncbi.nlm.nih.gov/pubmed/19336255

69. Hardwick JP. Cytochrome P450 omega hydroxylase (CYP4) function in fatty acid metabolism and metabolic diseases. Biochem Pharmacol. 2008;75(12):2263-75. 
70. Coon TA, Glasser JR, Mallampalli RK, Chen BB. Novel E3 ligase component FBXL7 ubiquitinates and degrades Aurora A, causing mitotic arrest. Cell cycle. 2012;11(4):721-9.

71. Katsha A, Soutto M, Sehdev V, Peng D, Washington MK, Piazuelo MB, et al. Aurora kinase A promotes inflammation and tumorigenesis in mice and human gastric neoplasia. Gastroenterology [Internet]. 2013 Dec;145(6):1312-22.e1-8. Available from: http://www.ncbi.nlm.nih.gov/pubmed/23993973

72. Fenner A. Prostate cancer: Orphan receptor GPR158 finds a home in prostate cancer growth and progression. Nat Rev Urol [Internet]. 2015 Apr;12(4):182. Available from: http://www.ncbi.nlm.nih.gov/pubmed/25753095

73. Li S, Zhu M, Pan R, Fang T, Cao Y-YY, Chen S, et al. The tumor suppressor PTEN has a critical role in antiviral innate immunity. Nat Immunol. 2016;17(3):241.

74. Vidotto T, Melo CM, Castelli E, Koti M, dos Reis RB, Squire JA. Emerging role of PTEN loss in evasion of the immune response to tumours. Br J Cancer [Internet]. 2020;122(12):1732-43. Available from: http://dx.doi.org/10.1038/s41416-020-0834-6

75. Lastwika KJ, Wilson W, Li QK, Norris J, Xu H, Ghazarian SR, et al. Control of PD-L1 Expression by Oncogenic Activation of the AKT-mTOR Pathway in Non-Small Cell Lung Cancer. Cancer Res [Internet]. 2016 Jan 15;76(2):227-38. Available from: http://www.ncbi.nlm.nih.gov/pubmed/26637667

76. Berghoff AS, Kiesel B, Widhalm G, Rajky O, Ricken G, Wöhrer A, et al. Programmed death ligand 1 expression and tumorinfiltrating lymphocytes in glioblastoma. Neuro Oncol [Internet]. 2015 Aug;17(8):1064-75. Available from: http://www.ncbi.nlm.nih.gov/pubmed/25355681

77. Martin AM, Nirschl TR, Nirschl CJ, Francica BJ, Kochel CM, van Bokhoven A, et al. Paucity of PD-L1 expression in prostate cancer: innate and adaptive immune resistance. Prostate Cancer Prostatic Dis [Internet]. 2015 Dec;18(4):325-32. Available from: http://www.ncbi.nlm.nih.gov/pubmed/26260996

78. Yuan H, Wei X, Zhang G, Li C, Zhang X, Hou J. B7-H3 over expression in prostate cancer promotes tumor cell progression. J Urol [Internet]. 2011 Sep;186(3):1093-9. Available from: http://www.ncbi.nlm.nih.gov/pubmed/21784485

79. Papanicolau-Sengos A, Yang Y, Pabla S, Lenzo FL, Kato S, Kurzrock R, et al. Identification of targets for prostate cancer $\begin{array}{llll}\text { immunotherapy. } & \text { Prostate } \quad \text { [Internet]. } & \text { Available }\end{array}$ http://www.ncbi.nlm.nih.gov/pubmed/30614027

80. Yang S, Wei W, Zhao Q. B7-H3, a checkpoint molecule, as a target for cancer immunotherapy. Int J Biol Sci [Internet]. 2020;16(11):1767-73. Available from: http://www.ncbi.nlm.nih.gov/pubmed/32398947

81. Benzon B, Zhao SG, Haffner MC, Takhar M, Erho N, Yousefi K, et al. Correlation of B7-H3 with androgen receptor, immune pathways and poor outcome in prostate cancer: an expression-based analysis. Prostate Cancer Prostatic Dis [Internet]. 
bioRxiv preprint doi: https://doi.org/10.1101/2020.10.08.332049; this version posted October 9, 2020. The copyright holder for this preprint

(which was not certified by peer review) is the author/funder, who has granted bioRxiv a license to display the preprint in perpetuity. It is made available under aCC-BY-NC 4.0 International license.

517 2017;20(1):28-35. Available from: http://www.ncbi.nlm.nih.gov/pubmed/27801901

¡18 82. Carver BS, Chapinski C, Wongvipat J, Hieronymus H, Chen Y, Chandarlapaty S, et al. Reciprocal feedback regulation of PI3K 519 and androgen receptor signaling in PTEN-deficient prostate cancer. Cancer Cell. 2011;19(5):575-86.

520 83. Gezer U, Tiryakioglu D, Bilgin E, Dalay N, Holdenrieder S. Androgen stimulation of PCA3 and miR-141 and their release from $521 \quad$ prostate cancer cells. Cell J. 2015;16(4):488.

522 84. Parolia A, Crea F, Xue H, Wang Y, Mo F, Ramnarine VR, et al. The long non-coding RNA PCGEM1 is regulated by androgen receptor activity in vivo. Mol Cancer. 2015;14(1):46. 
bioRxiv preprint doi: https://doi.org/10.1101/2020.10.08.332049; this version posted October 9,2020 . The copyright holder for this preprint

(which was not certified by peer review) is the author/funder, who has granted bioRxiv a license to display the preprint in perpetuity. It is made available under aCC-BY-NC 4.0 International license.

\section{$§ 25 \quad$ Figures and Tables}

\begin{tabular}{lrrc}
\hline Cohort & PTEN-null & PTEN-intact & N \\
\hline TCGA & 95 & 321 & 416 \\
HPFS & 91 & 299 & 390 \\
Natural History & 56 & 151 & 207 \\
\hline Total & 242 & 771 & 1,013 \\
\hline
\end{tabular}

¡27 Table 1. Cohorts summary Table shows cohorts summary for the 3 cohorts used in this study: TCGA (only primary tumor samples ¡28 with high Gistic scores were used); Health Professional Follow-up Study (all); and Natural History cohort (samples with IHC call available). PTEN-null represents samples with PTEN deletion and PTEN-intact regular primary tumors. 
bioRxiv preprint doi: https://doi.org/10.1101/2020.10.08.332049; this version posted October 9, 2020. The copyright holder for this preprint (which was not certified by peer review) is the author/funder, who has granted bioRxiv a license to display the preprint in perpetuity. It is made available under aCC-BY-NC 4.0 International license.

\begin{tabular}{lccc}
\hline & PTEN-null vs PTEN-intact overall & PTEN-null vs PTEN-intact in ERG+ & PTEN-null vs PTEN-intact in ERG- \\
\hline Coding genes & $257(13)$ & $226(7)$ & $185(10)$ \\
Non-coding genes & $264(134)$ & $209(117)$ \\
\hline Total & $521(137)$ & $435(124)$
\end{tabular}

¡33 Table 2. Summary of differentially expressed genes between PTEN-null and PTEN-intact with logFC $\geq 1$ and FDR $\leq 0.01$ across

¡34 different ERG backgrounds. Number in parenthesis shows the number of genes exclusive to the FANTOM-CAT annotations. 


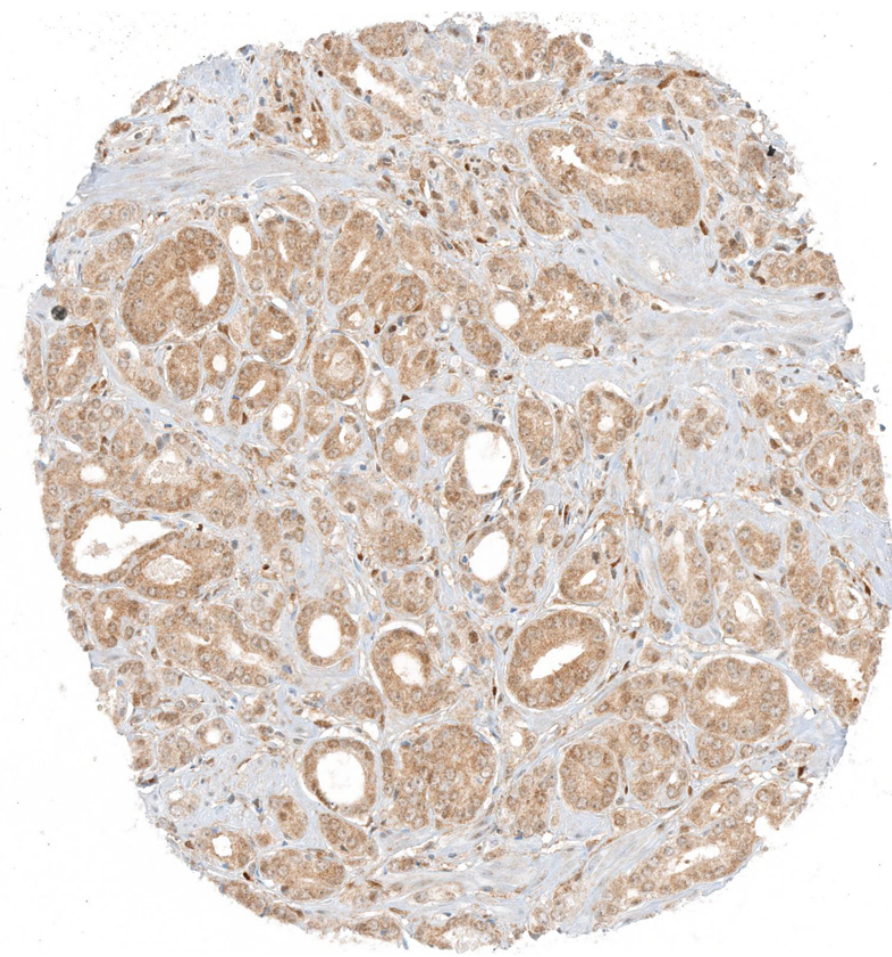

PTEN intact

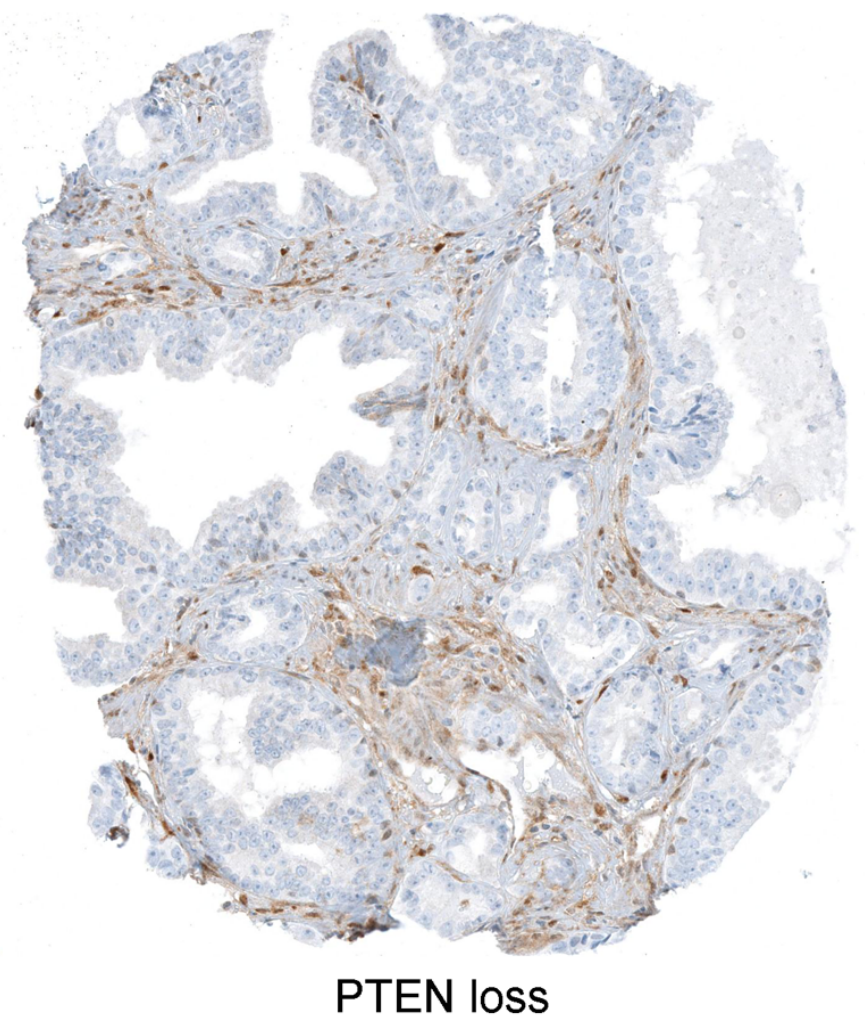

PTEN loss

Figure 1. PTEN immunostaining in tissue microarray (TMA) spots from the Natural History Cohort. Left panel: intact PTEN protein

is present in all sampled tumor glands (brown chromogen). Right panel: PTEN loss in all sampled tumor glands. Images reduced

from 40X. 
bioRxiv preprint doi: https://doi org/10.1101/202010.08 332049. this version posted October 9 2020. The copyright holder for this preprint (which was not certified by peer review) is the author/funder, who has granted bioRxiv a license to display the preprint in perpetuity. It is made available under aCC-BY-NC 4.0 International license.

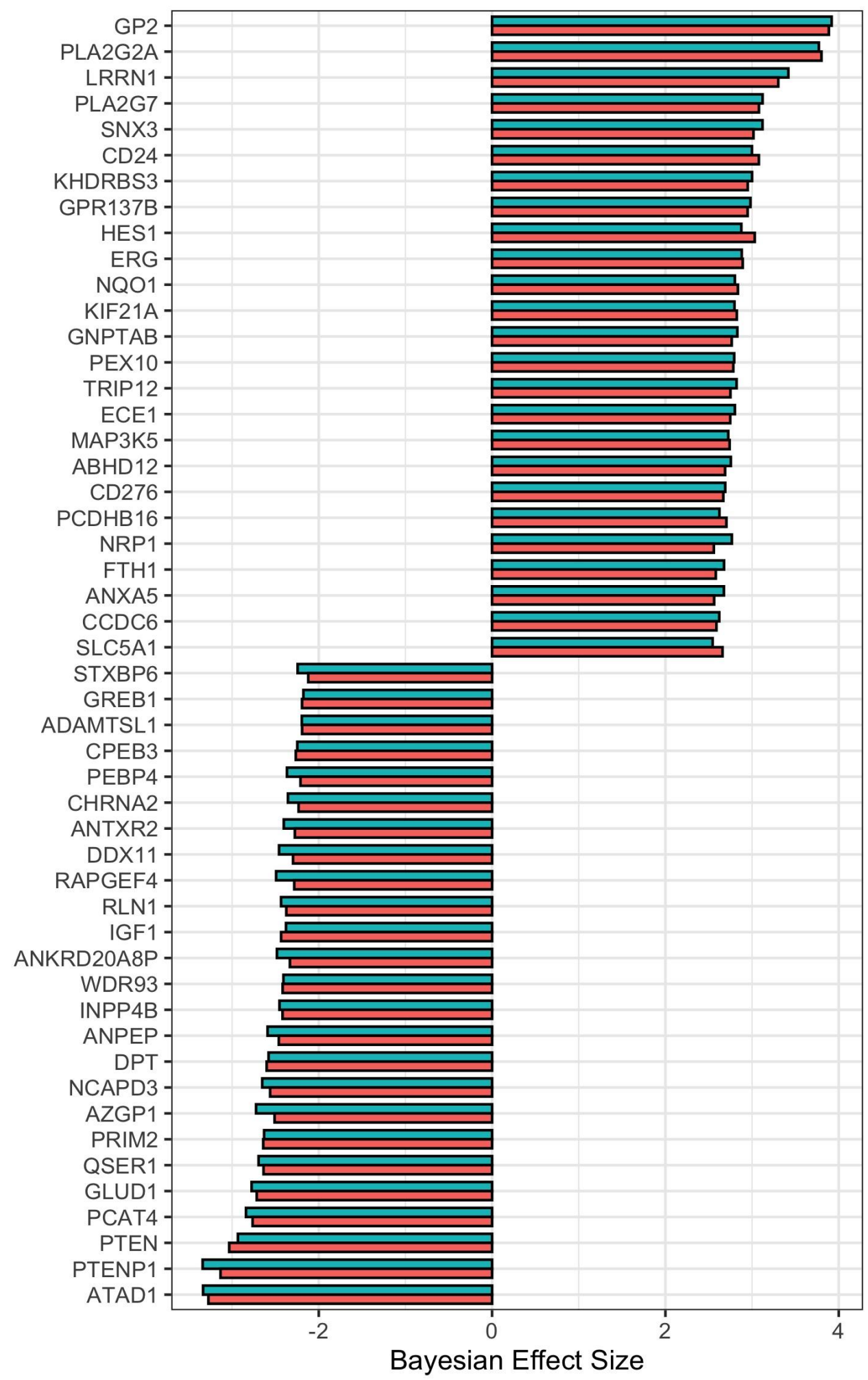

Natural History

HPFS/HPS

Figure 2. Cross-study meta-analysis of differential gene expression. Genes in the same loci as PTEN such as RLN1 and ATAD1 
bioRxiv preprint doi: https://doi.org/10.1101/2020.10.08.332049; this version posted October 9, 2020. The copyright holder for this preprint (which was not certified by peer review) is the author/funder, who has granted bioRxiv a license to display the preprint in perpetuity. It is made available under aCC-BY-NC 4.0 International license.

542 Model for DGE using XDE showing the top 25 most concordant differentially up- and down-regulated genes. PTEN status were ¡43 based on IHC assays.

544 
bioRxiv preprint doi: https://doi. org/10.1101/2020.10.08 332049. this version posted October 9 2020. The copyright holder for this preprint (which was not certified by peer review) is the author/funder, who has granted bioRxiv a license to display the preprint in perpetuity. It is made available under aCC-BY-NC 4.0 International license.

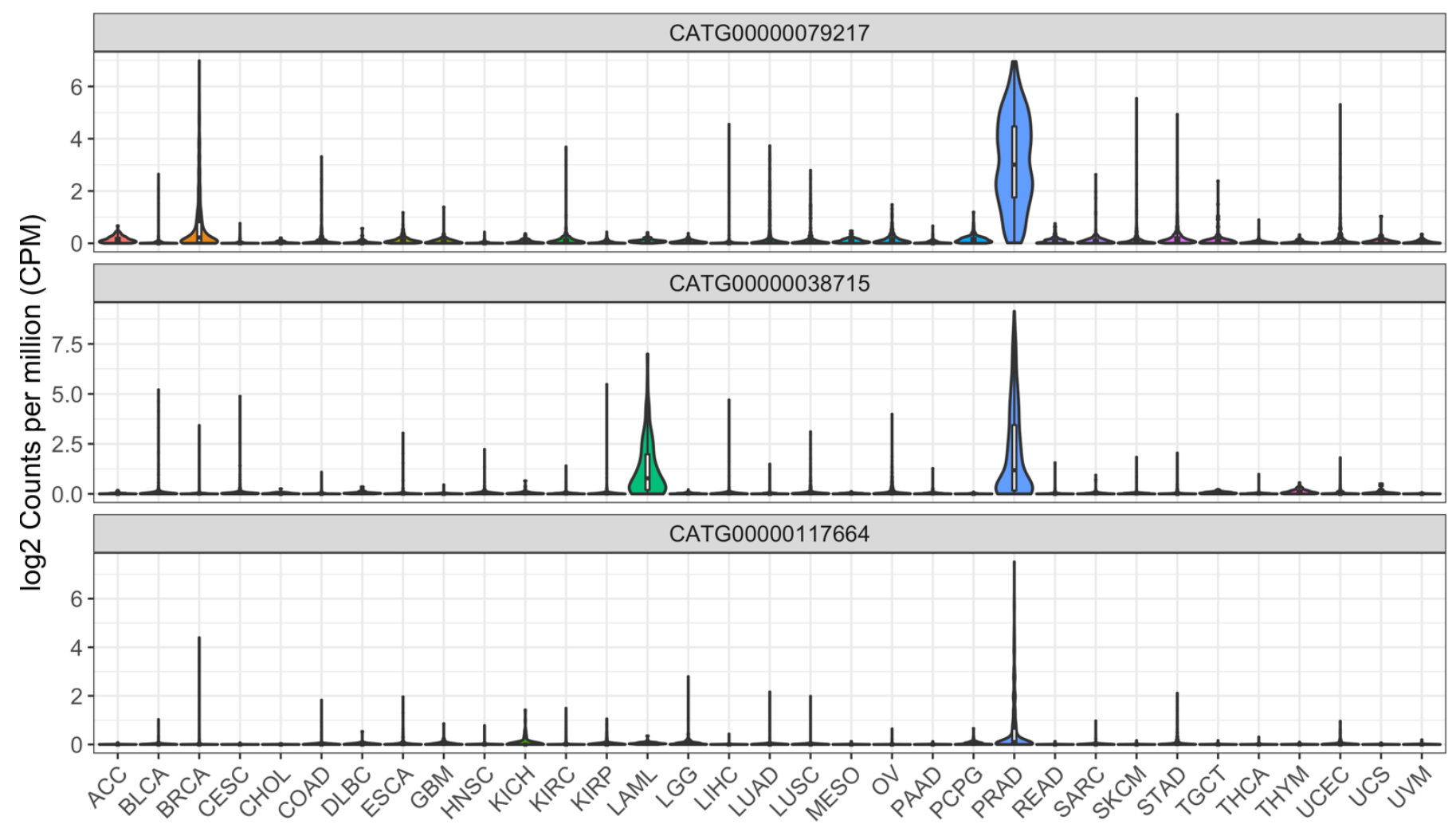

Figure 3. Expression profiles of novel FANTOM-CAT genes CATG00000038715, CATG00000079217 and CATG00000117664 across

33 cancer types. Violin-plots shows expression $\left(\log _{2} \mathrm{CPM}+1\right)$ distribution. 


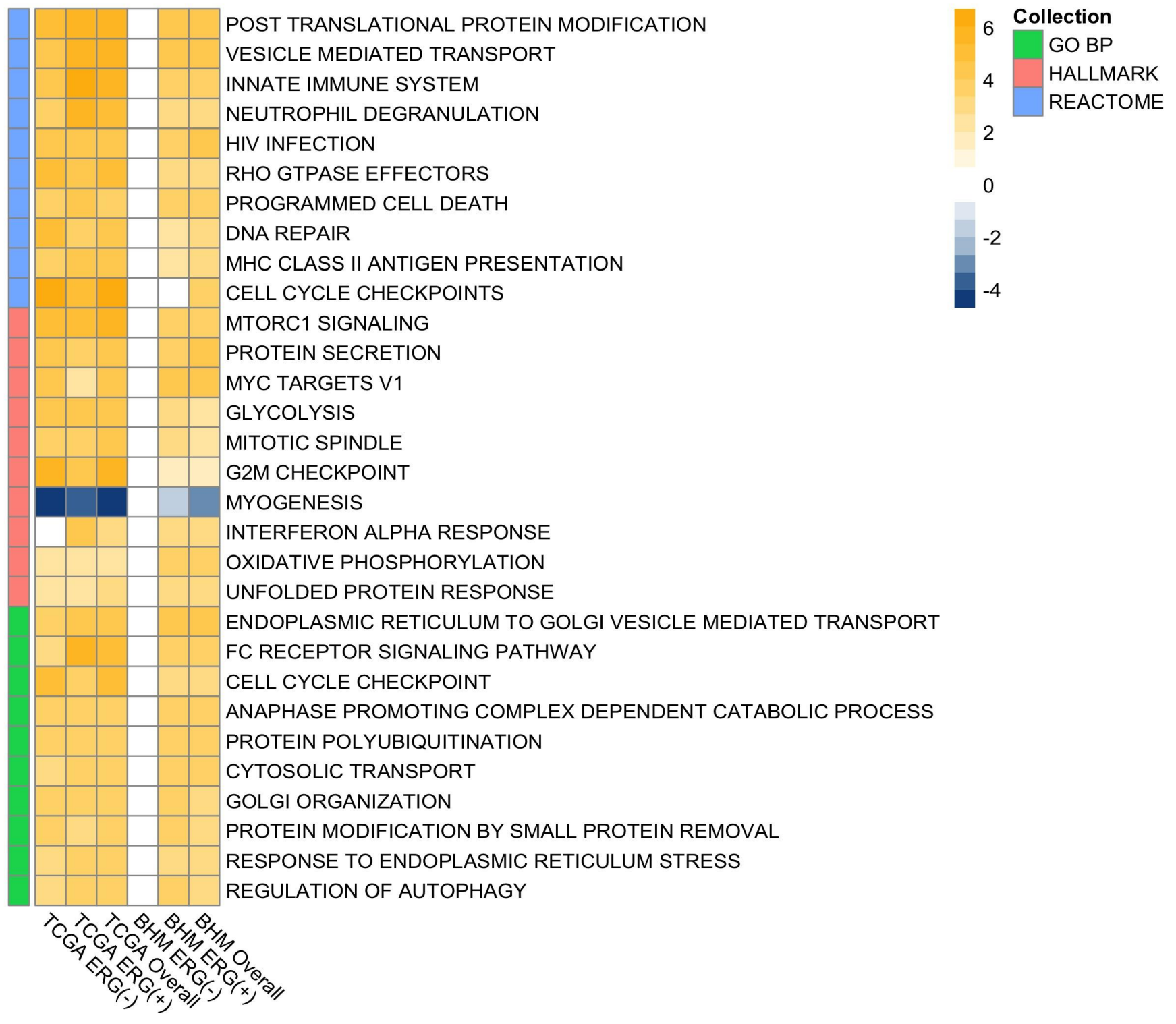

Figure 4. Top enriched gene sets enriched across PTEN-null and PTEN-intact in the TCGA and BHM cohorts stratified by ERG showing the top 10 enriched gene sets of each collection (ranked by signed p-value). 


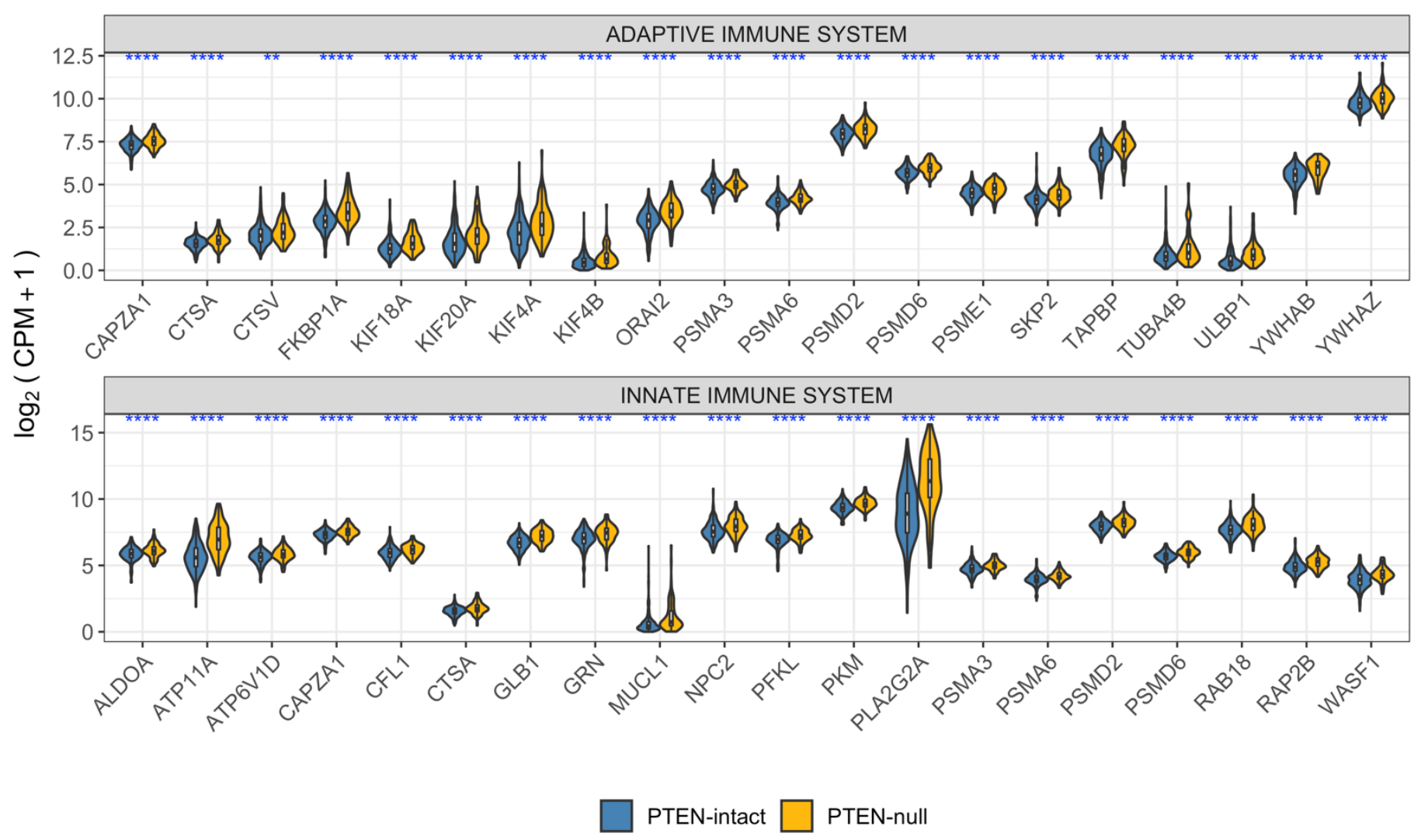

Figure 5. Expression of immune-related genes stratified by PTEN status. Top 20 were selected based on the leading edge of the

GSEA of the adaptive and innate immune system gene sets from REACTOME. Significances based on t-test between PTEN-null and

PTEN-intact using $\log _{2} \mathrm{CPM}+1$ values. Significance cutoffs: ${ }^{*}=\leq 0.05 ; * * \leq 0.01 ; * * * \leq 0.001 ; * * * * \leq 0.0001$. 
bioRxiv preprint doi: https://doi.org/10.1101/2020 10.08 332049; this version posted October 9 2020. The copyright holder for this preprint (which was not certified by peer review) is the author/funder, who has granted bioRxiv a license to display the preprint in perpetuity. It is made available under aCC-BY-NC 4.0 International license.

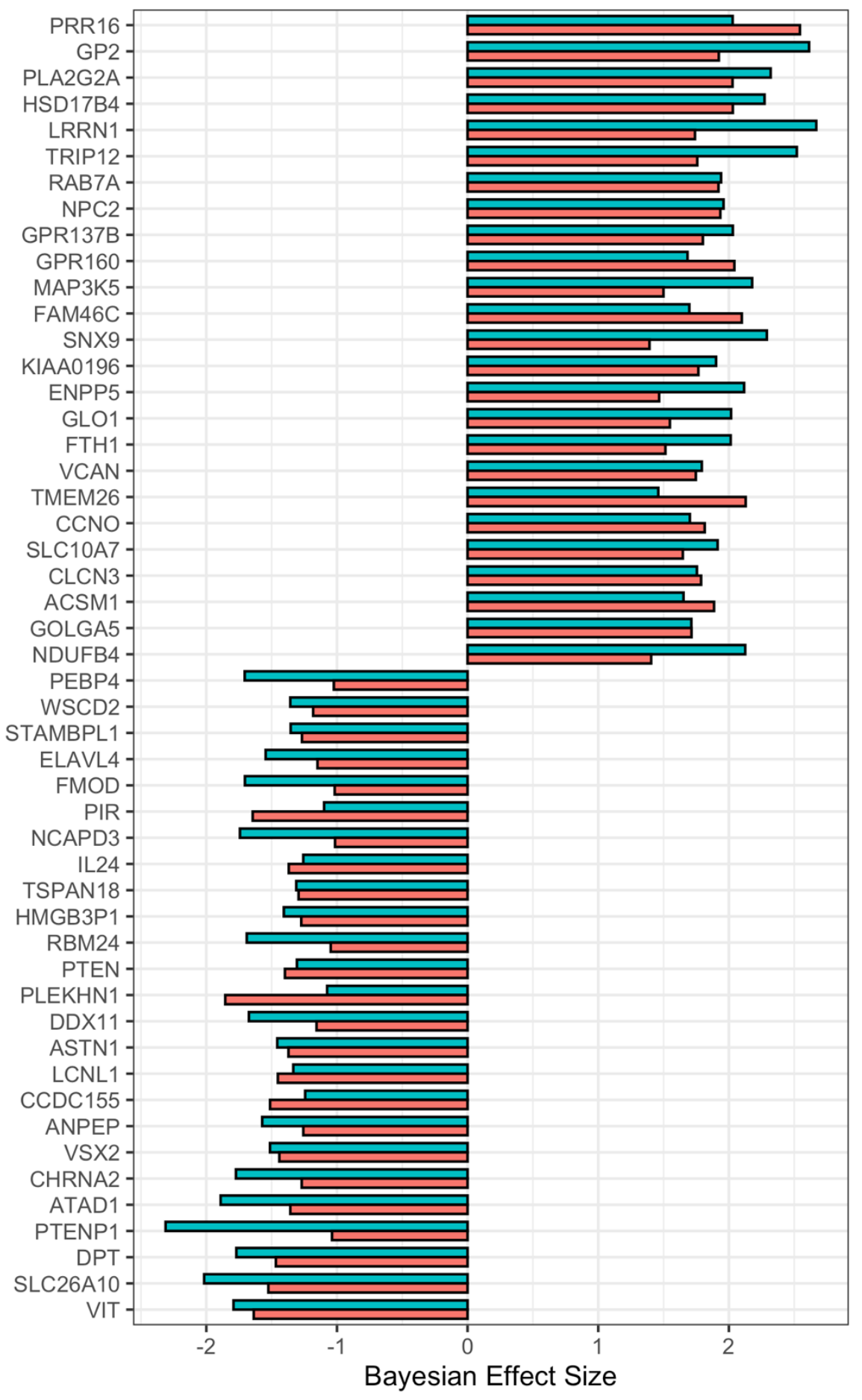

Natural History

HPFS/HPS 
bioRxiv preprint doi: https://doi.org/10.1101/2020.10.08.332049; this version posted October 9, 2020. The copyright holder for this preprint (which was not certified by peer review) is the author/funder, who has granted bioRxiv a license to display the preprint in perpetuity. It is made available under aCC-BY-NC 4.0 International license.

j64 Figure S1. Cross-study of differential gene expression in PTEN-null vs PTEN-intact in ERG ${ }^{+}$samples. Meta-analysis of HPFS/PHS

565 and NH cohorts with Bayesian Hierarchical Model for DGE using XDE showing the top 25 most concordant differentially up- and j66 down-regulated genes. PTEN status were based on IHC assays. 


\section{PTEN expression stratified by PTEN copy number status}

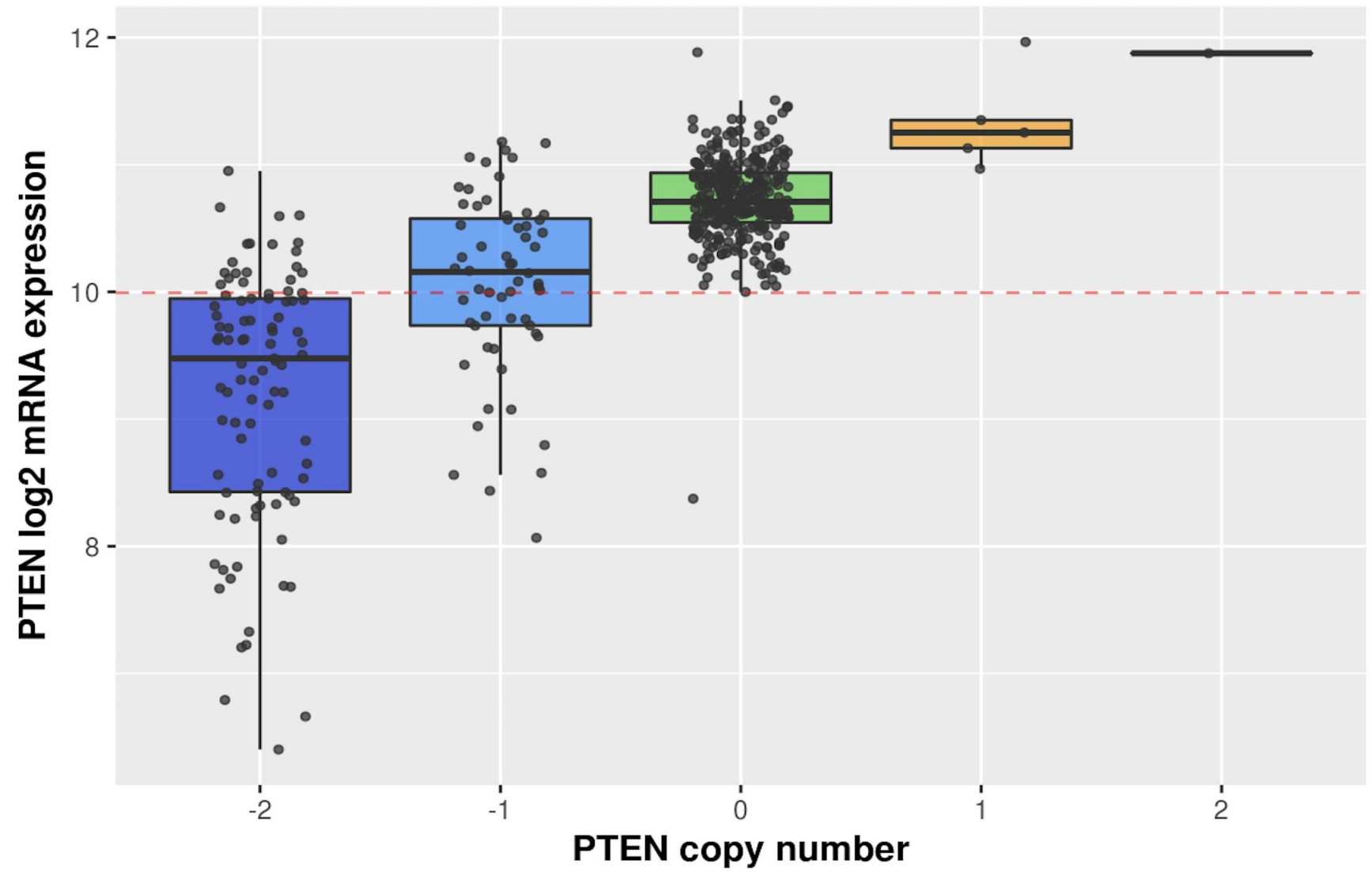

Figure S3. PTEN expression levels stratified by CNV. Figure shows PTEN expression levels distribution by copy number variation 


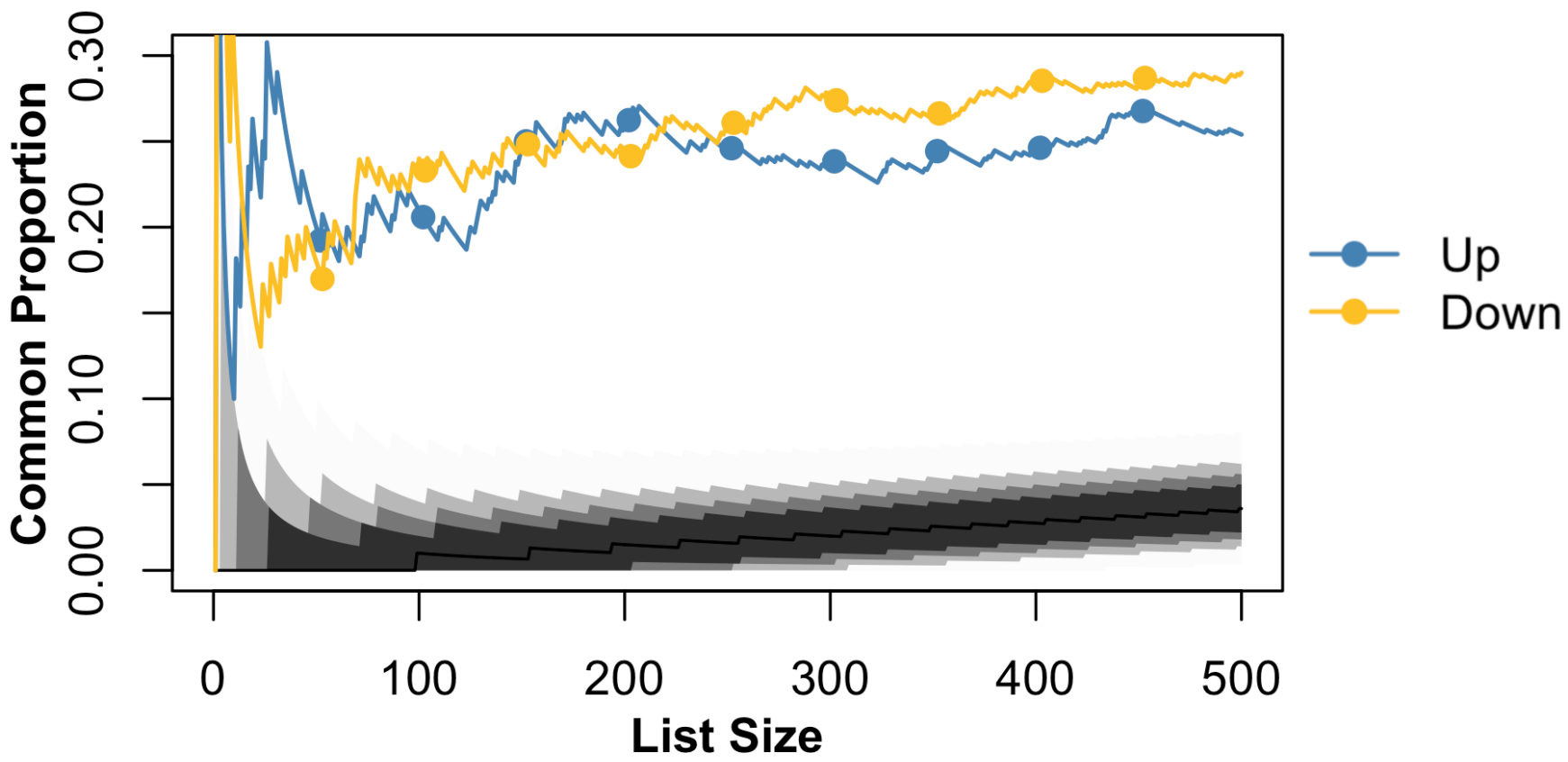

573 Figure S4. Correspondence-at-the-top (CAT) plot between TCGA CNV-based calls and the Bayesian Hierarchical Model approach 574 (BHM). Agreement of genes ranked by t-statistics (TCGA) and average Bayesian Effect Size (BHM). Lines represent agreement j75 between tested cohorts for PTEN-intact vs PTEN-null. Black-to-light grey shades represent the decreasing probability of agreeing by chance based on the hypergeometric distribution, with intervals ranging from 0.999999 (light grey) to 0.95 (dark grey). Lines outside this range represent agreement in different cohorts with a higher agreement than expected by chance. 
bioRxiv preprint doi: https://doi.org/10.1101/2020 10.08 332049; this version posted October 9,2020. The copyright holder for this preprint (which was not certified by peer review) is the author/funder, who has granted bioRxiv a license to display the preprint in perpetuity. It is made available under aCC-BY-NC 4.0 International license.
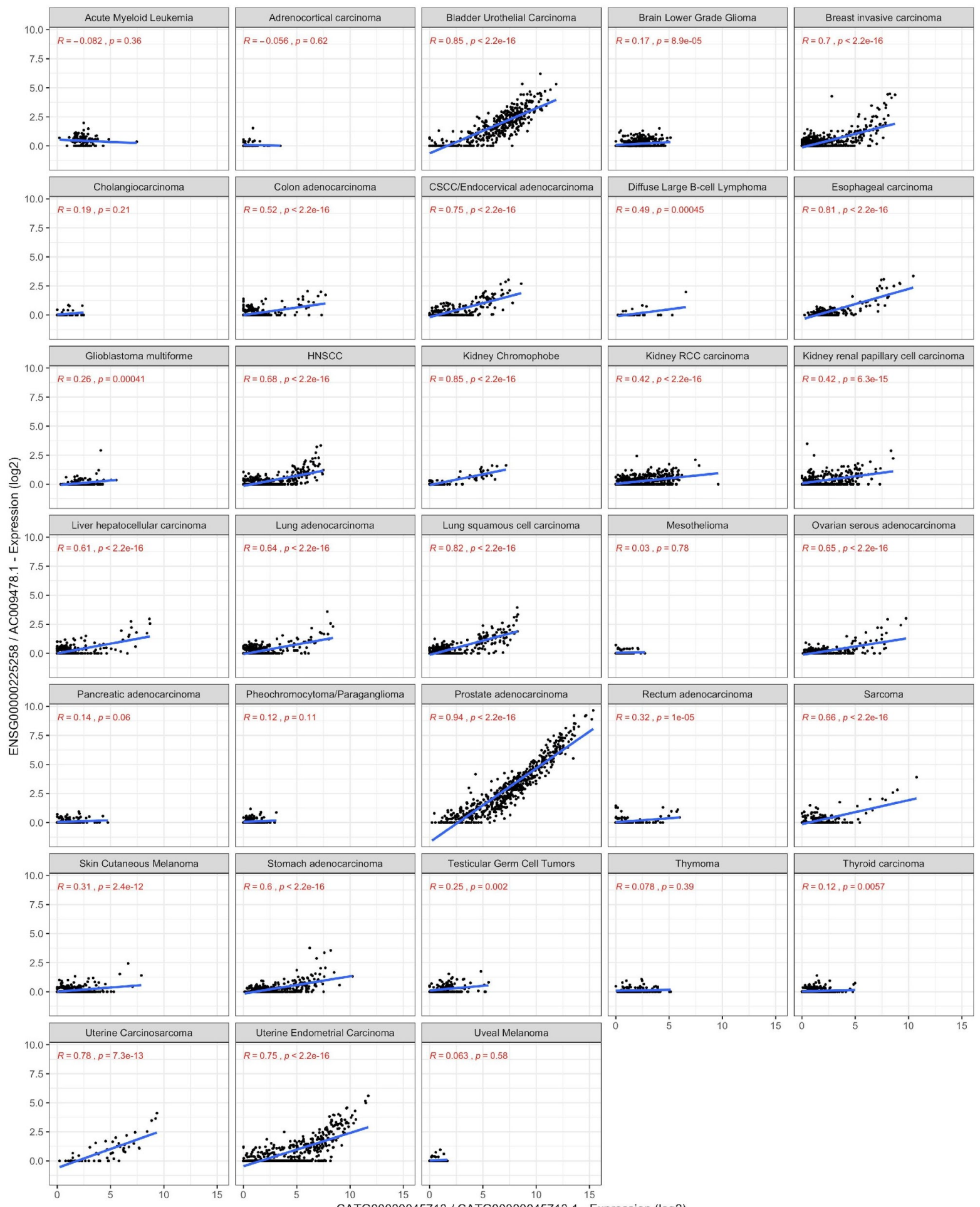

Figure S5. Expression of AC009478.1 is shown to be highly specific to PRAD, BLCA, to a lesser extent in UECA and BRCA. Figure

red. 
bioRxiv preprint doi: https://doi.org/10.1101/2020.10.08.332049; this version posted October 9, 2020. The copyright holder for this preprint (which was not certified by peer review) is the author/funder, who has granted bioRxiv a license to display the preprint in perpetuity. It is made available under aCC-BY-NC 4.0 International license.

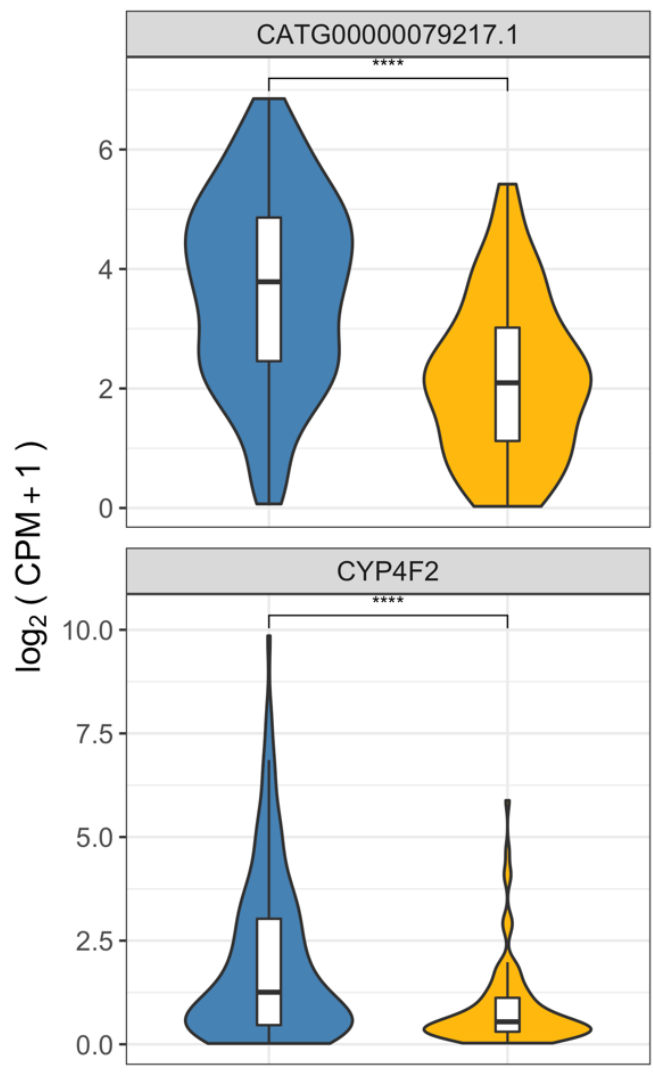
$* * * * \leq 0.0001$.
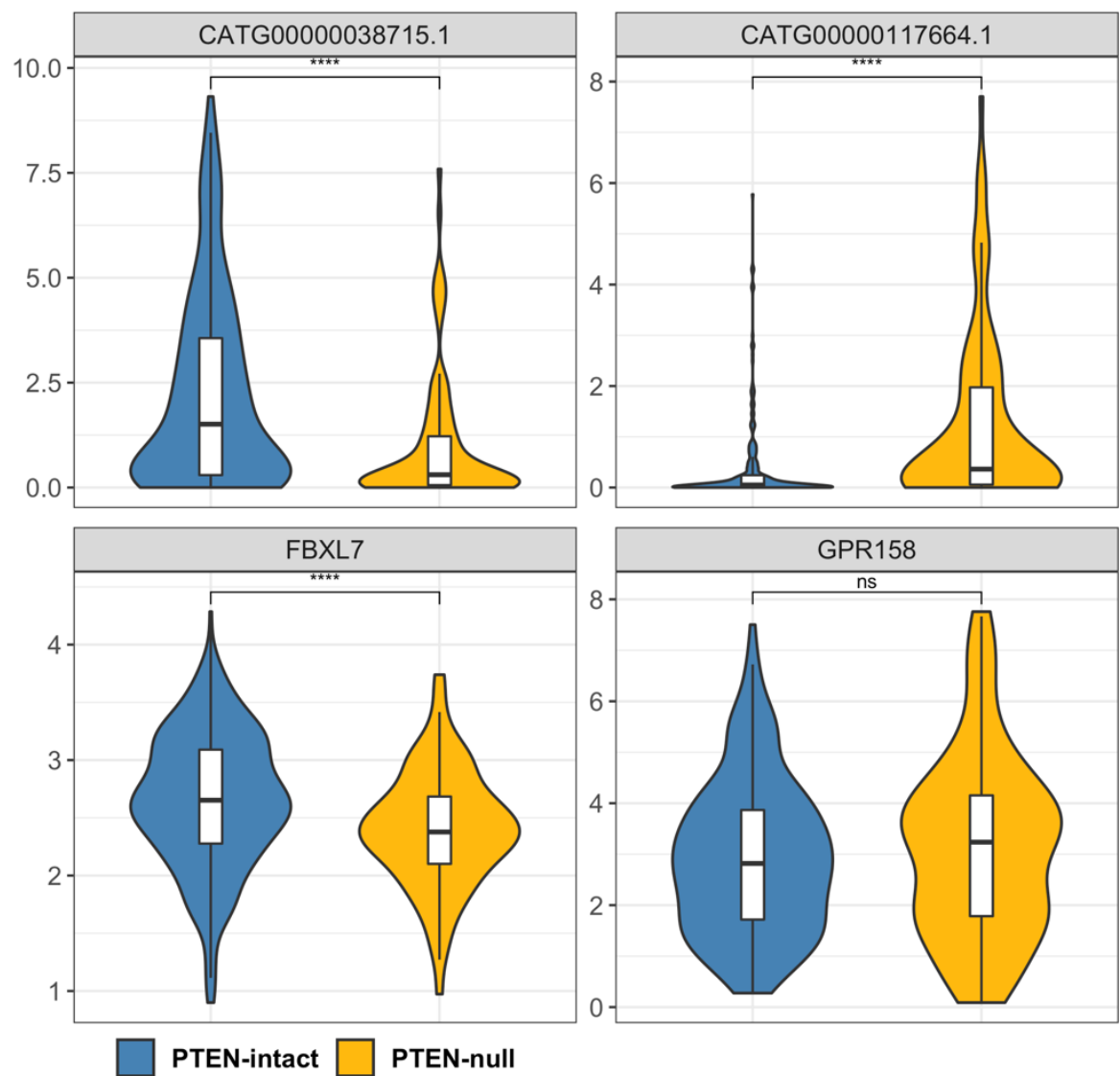

Figure S6. Expression of FANTOM-CAT IncRNAs genes (top) and close coding genes (bottom) stratified by PTEN status. Significances based on t-test between PTEN-null and PTEN-intact using $\log _{2}$ CPM+1 value. Significance cutoffs: ${ }^{*}=\leq 0.05 ; * * \leq 0.01 ; * * * \leq 0.001$; 
bioRxiv preprint doi: https://doi.org/10.1101/2020.10.08.332049; this version posted October 9, 2020. The copyright holder for this preprint (which was not certified by peer review) is the author/funder, who has granted bioRxiv a license to display the preprint in perpetuity. It is made available under aCC-BY-NC 4.0 International license.

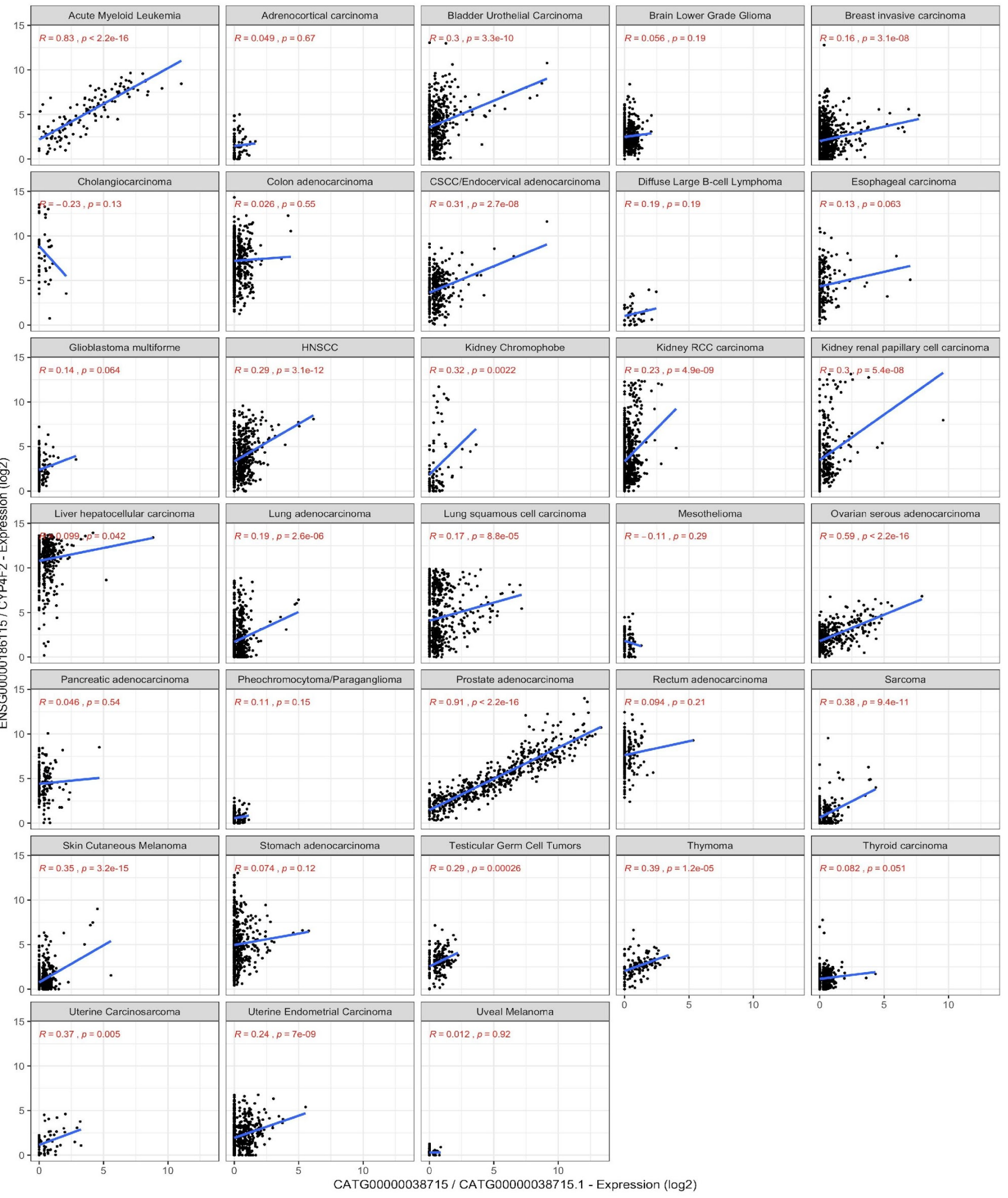

Figure S7. Person correlation gene CATG00000038715 and CYP4F2 across cancer types. CATG00000038715 and CYP4F2 
bioRxiv preprint doi: https://doi.org/10.1101/2020.10.08.332049; this version posted October 9,2020 . The copyright holder for this preprint (which was not certified by peer review) is the author/funder, who has granted bioRxiv a license to display the preprint in perpetuity. It is made available under aCC-BY-NC 4.0 International license. 
bioRxiv preprint doi: https://doi. org/10.1101/2020 10.08.332049; this version posted October 9,2020 . The copyright holder for this preprint (which was not certified by peer review) is the author/funder, who has granted bioRxiv a license to display the preprint in perpetuity. It is made available under aCC-BY-NC 4.0 International license.
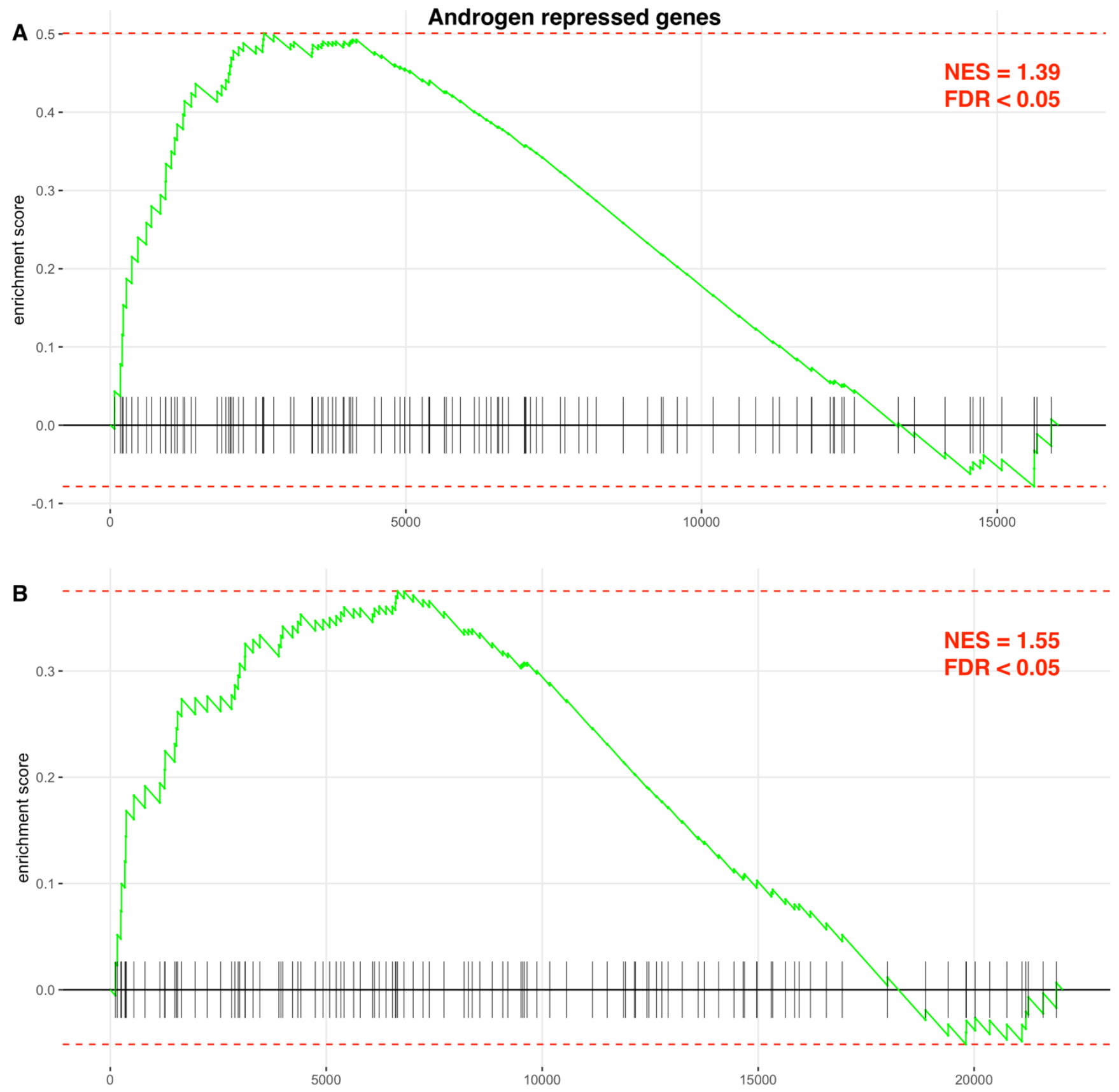

Figure S8. Gene set enrichment for Androgen repressed genes. Gene set enrichment analysis of gene signature showing positive enrichment of genes repressed by dihydrotestosterone after 6 hours of exposure obtained from Schaeffer et al. ${ }^{48}$. Enrichment for BHM-signature is shown in panel A and TCGA-signature in panel B. 
bioRxiv preprint doi: https://doi.org/10.1101/2020.10.08.332049; this version posted October 9, 2020. The copyright holder for this preprint (which was not certified by peer review) is the author/funder, who has granted bioRxiv a license to display the preprint in perpetuity. It is made available under aCC-BY-NC 4.0 International license. 